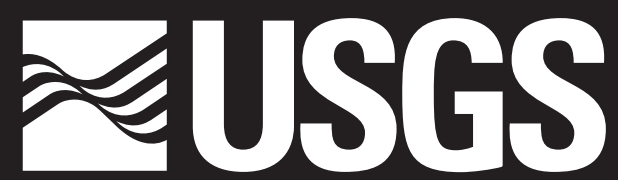

science for a changing world

Prepared in cooperation with the

Metropolitan District Commission

\title{
Surface-Water Quality and Nutrient Loads in the Nepaug Reservoir Watershed, Northwestern Connecticut, 1999-2001
}

Scientific Investigations Report 2006-5272 


\section{Surface-Water Quality and Nutrient Loads in the Nepaug Reservoir Watershed, Northwestern Connecticut, 1999-2001}

By Jonathan Morrison and Michael J. Colombo

Prepared in cooperation with the Metropolitan District Commission

Scientific Investigations Report 2006-5272 


\title{
U.S. Department of the Interior DIRK KEMPTHORNE, Secretary
}

\author{
U.S. Geological Survey \\ Mark D. Myers, Director
}

\section{U.S. Geological Survey, Reston, Virginia: 2006}

For product and ordering information:

World Wide Web: http://www.usgs.gov/pubprod

Telephone: 1-888-ASK-USGS

For more information on the USGS - the Federal source for science about the Earth, its natural and living resources, natural hazards, and the environment:

World Wide Web: http://www.usgs.gov

Telephone: 1-888-ASK-USGS

Any use of trade, product, or firm names is for descriptive purposes only and does not imply endorsement by the U.S. Government.

Although this report is in the public domain, permission must be secured from the individual copyright owners to reproduce any copyrighted materials contained within this report.

Suggested citation:

Morrison, Jonathan, and Colombo, M.J., 2006, Surface-water quality and nutrient loads in the Nepaug Reservoir watershed, northwestern Connecticut, 1999-2001: U.S. Geological Survey Scientific Investigations Report 2006-5272, $36 \mathrm{p}$. 


\section{Contents}

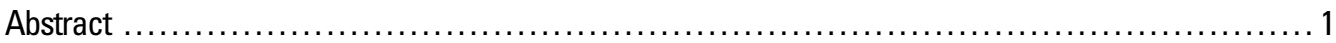

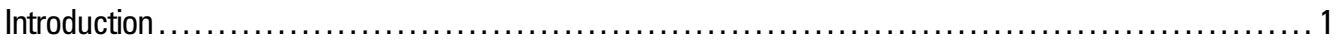

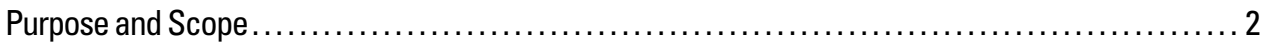

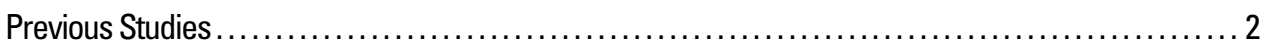

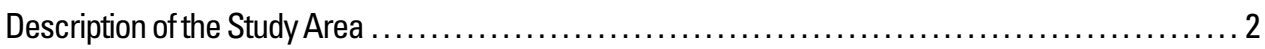

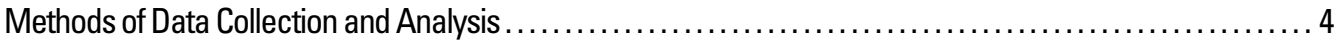

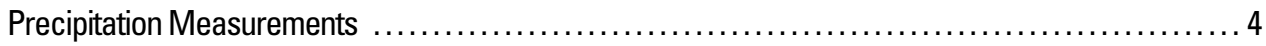

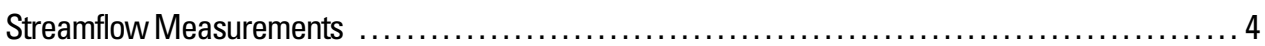

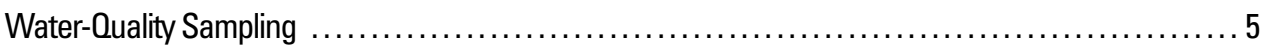

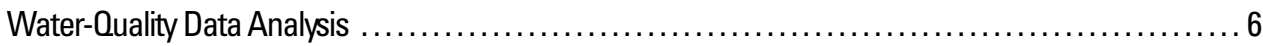

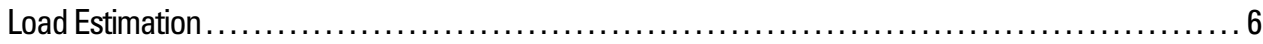

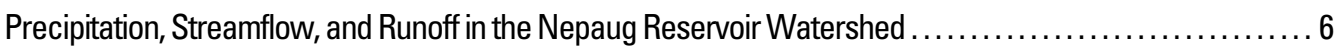

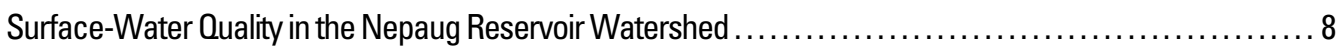

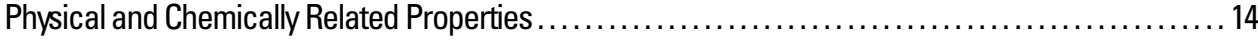

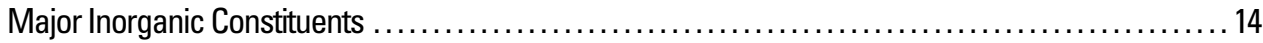

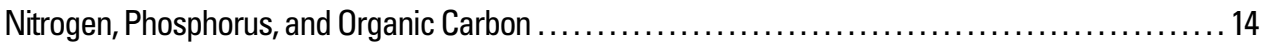

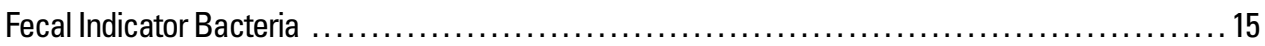

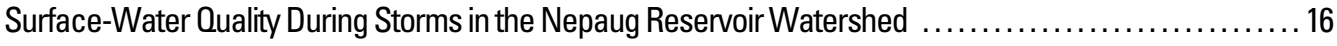

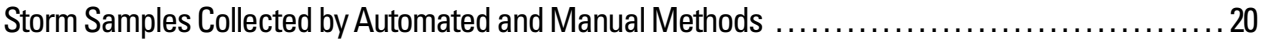

Physical and Chemically Related Properties .................................. 20

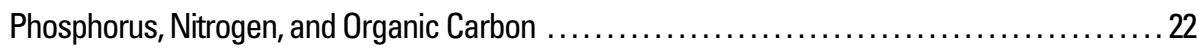

Storm Samples Collected by Automated Composite Methods ............................ 25

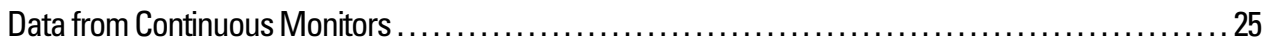

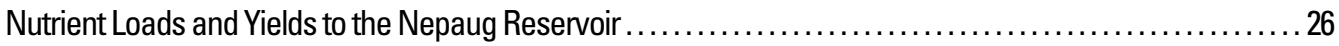

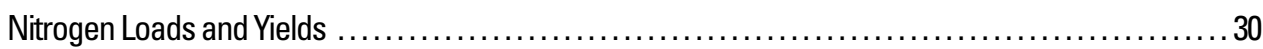

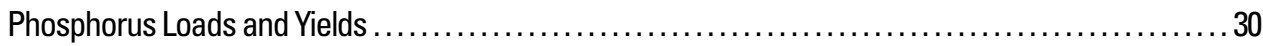

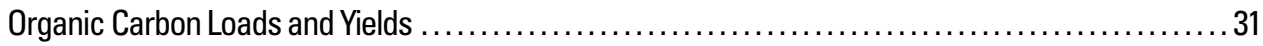

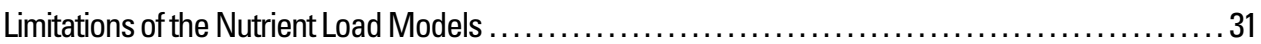

Comparison of Yields in the Nepaug Reservoir Watershed to Other Watersheds in Connecticut ...... 32

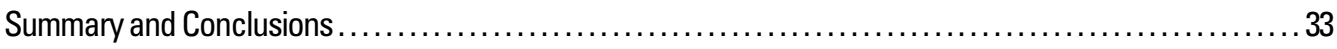

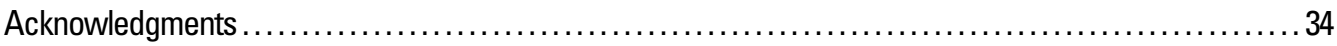

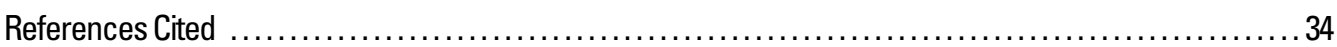




\section{Figures}

1. Map showing location of the Nepaug Reservoir watershed and the North and South Areas, northwestern Connecticut

2-12. Graphs showing:

2. Precipitation at Burlington, Connecticut, water years 1999-2001

3. Streamflow at three U.S. Geological Survey stations indicating dates and flow conditions when water samples were collected, water years 1999-2001: $A$, station 01187800 Nepaug River near Nepaug, Connecticut, $B$, station 01187830 Phelps Brook near Collinsville, Connecticut; and $C$, station 01187850 Clear Brook near Collinsville, Connecticut..............9

4. Streamflow in $A$, Nepaug River and Clear Brook; and B, Phelps Brook and Clear Brook, adjusted by size of drainage basin, for water years 1999-2001 .9

5. Flow-duration curves showing streamflow normalized by drainage area at three U.S. Geological Survey stations during the study period and the long-term period of record: $A$, station 01187800 Nepaug River near Nepaug, Connecticut; $B$, station 01187830 Phelps Brook near Collinsville, Connecticut; and $C$, station 01187850 Clear Brook near Collinsville, Connecticut.... 11

6. The distribution of the concentrations of $A$, fecal coliform bacteria; and $B$, enterococci bacteria, Nepaug Reservoir watershed, Connecticut.

7. The distribution of the concentrations of fecal coliform bacteria by season at three U.S. Geological Survey stations, 1999-2001: A, station 01187800 Nepaug River near Nepaug, Connecticut; $B$, station 01187830 Phelps Brook near Collinsville, Connecticut; and $C$, station 01187850 Clear Brook near Collinsville, Connecticut ....

8. The distribution of the concentrations of enterococci bacteria by season at three U.S. Geological Survey stations, 1999-2001: A, station 01187800 Nepaug River near Nepaug, Connecticut; $B$, station 01187830 Phelps Brook near Collinsville, Connecticut; and $C$, station 01187850 Clear Brook near Collinsville, Connecticut

9. Continuous water-quality-monitoring data and concentration of total phosphorus at two U.S. Geological Survey stations: $A$, station 01187800 Nepaug River near Nepaug, Connecticut; and $B$, station 01187830 Phelps Brook near Collinsville, Connecticut, March 10-14, 2000 .

10. Continuous water-quality-monitoring data and concentration of total phosphorus at $A$, station 01187850 Clear Brook near Collinsville, Connecticut; and $B$, station 01187800 Nepaug River near Nepaug, Connecticut, May 19-21, 1999

11. Relation of total phosphorus to turbidity at three U.S. Geological Survey stations: $A$, station 01187800 Nepaug River near Nepaug, Connecticut; $B$, station 01187830 Phelps Brook near Collinsville, Connecticut; and $C$, station 01187850 Clear Brook near Collinsville, Connecticut

12. Continuous water-quality-monitoring data, U.S. Geological Survey station 01187850

Clear Brook near Collinsville, Connecticut, September 14-21, 1999

\section{Tables}

1. U.S. Geological Survey stations in the Nepaug Reservoir watershed used for this study . . . . . . . . . 4

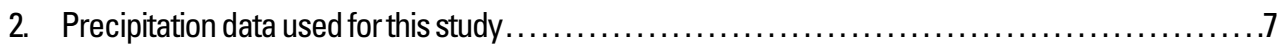

3. Statistical summary of surface-water data for U.S. Geological Survey stations in the Nepaug

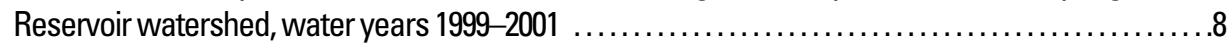

4. Statistical summary of monthly water-quality data for U.S. Geological Survey stations in the Nepaug Reservoir watershed, water years 1999-2001.

5. Statistical summary of fecal coliform and enterococci bacteria data for U.S. Geological Survey stations in the Nepaug Reservoir watershed, water years 1999-2001 . . 
6. Sampled storms in the Nepaug Reservoir watershed during the study period ................ 20

7. Statistical summary of water-quality data for selected storms during the study period for U.S. Geological Survey stations in the Nepaug Reservoir watershed

8. Explanatory variable terms, term coefficients, and coefficients of determination used in nutrient load estimates for tributaries to the Nepaug Reservoir

9. Annual loads and yields of nutrients and total organic carbon for U.S. Geological Survey stations in the Nepaug Reservoir watershed....

10. Example of a storm-load calculation of total phosphorus and total nitrogen by LOADEST and mass-integration methods for U.S. Geological Survey stations in the Nepaug Reservoir watershed, May 1999

\section{Conversion Factors, Abbreviations, and Datums}

\begin{tabular}{|c|c|c|}
\hline Multiply & By & To obtain \\
\hline \multicolumn{3}{|c|}{ Length } \\
\hline inch (in.) & 25.4 & millimeter $(\mathrm{mm})$ \\
\hline foot $(\mathrm{ft})$ & 0.3048 & meter $(\mathrm{m})$ \\
\hline mile (mi) & 1.609 & kilometer $(\mathrm{km})$ \\
\hline \multicolumn{3}{|c|}{ Area } \\
\hline acre & 0.4047 & hectare (ha) \\
\hline square mile $\left(\mathrm{mi}^{2}\right)$ & 2.590 & square kilometer $\left(\mathrm{km}^{2}\right)$ \\
\hline \multicolumn{3}{|c|}{ Volume } \\
\hline cubic foot $\left(\left(\mathrm{ft}^{3}\right)\right.$ & 0.02832 & cubic meter $\left(\mathrm{m}^{3}\right)$ \\
\hline \multicolumn{3}{|c|}{ Flow rate } \\
\hline cubic foot per second $\left(\mathrm{ft}^{3} / \mathrm{s}\right)$ & 0.02832 & cubic meter per second $\left(\mathrm{m}^{3} / \mathrm{s}\right)$ \\
\hline $\begin{array}{l}\text { cubic foot per second per square mile } \\
{\left[\left(\mathrm{ft}^{3} / \mathrm{s}\right) / \mathrm{mi}^{2}\right]}\end{array}$ & 0.01093 & $\begin{array}{l}\text { cubic meter per second per square } \\
\text { kilometer }\left[\left(\mathrm{m}^{3} / \mathrm{s}\right) / \mathrm{km}^{2}\right]\end{array}$ \\
\hline inch per hour (in/h) & 0.0254 & meter per hour $(\mathrm{m} / \mathrm{h})$ \\
\hline inch per year (in/yr) & 25.4 & millimeter per year $(\mathrm{mm} / \mathrm{yr})$ \\
\hline \multicolumn{3}{|c|}{ Mass } \\
\hline pound, avoirdupois (lb) & 0.4536 & kilogram $(\mathrm{kg})$ \\
\hline $\begin{array}{l}\text { ton per day per square mile } \\
{\left[(\text { ton } / \mathrm{d}) / \mathrm{mi}^{2}\right]}\end{array}$ & 0.3503 & $\begin{array}{l}\text { megagram per day per square kilo- } \\
\text { meter }\left[(\mathrm{Mg} / \mathrm{d}) / \mathrm{km}^{2}\right]\end{array}$ \\
\hline $\begin{array}{l}\text { pound per square mile per year } \\
\left(\mathrm{lb} / \mathrm{mi}^{2} / \mathrm{yr}\right)\end{array}$ & 0.1751 & $\begin{array}{l}\text { kilogram per square kilometer per year } \\
\left(\mathrm{kg} / \mathrm{km}^{2} / \mathrm{yr}\right)\end{array}$ \\
\hline
\end{tabular}

Temperature in degrees Celsius $\left({ }^{\circ} \mathrm{C}\right)$ may be converted to degrees Fahrenheit ( $\left.{ }^{\circ} \mathrm{F}\right)$ as follows: ${ }^{\circ} \mathrm{F}=\left(1.8 \times{ }^{\circ} \mathrm{C}\right)+32$

Temperature in degrees Fahrenheit ( $\left.{ }^{\circ} \mathrm{F}\right)$ may be converted to degrees Celsius $\left({ }^{\circ} \mathrm{C}\right)$ as follows: ${ }^{\circ} \mathrm{C}=\left({ }^{\circ} \mathrm{F}-32\right) / 1.8$

Specific conductance is given in microsiemens per centimeter at 25 degrees Celsius $(\mu \mathrm{S} / \mathrm{cm}$ at $\left.25^{\circ} \mathrm{C}\right)$.

Concentrations of chemical constituents in water are given either in milligrams per liter (mg/L) or micrograms per liter $(\mu \mathrm{g} / \mathrm{L})$.

Vertical coordinate information is referenced to the North American Vertical Datum of 1988 (NAVD 88). Horizontal coordinate information is referenced to North American Datum of 1983 (NAD 83).

Altitude, as used in this report, refers to distance above the vertical datum. 



\title{
Surface-Water Quality and Nutrient Loads in the Nepaug Reservoir Watershed, Northwestern Connecticut, 1999-2001
}

\author{
By Jonathan Morrison and Michael J. Colombo
}

\section{Abstract}

Water quality was characterized at three tributary watersheds to the Nepaug Reservoir-Nepaug River, Phelps Brook, and Clear Brook-from October 1998 through September 2001 to document existing water-quality conditions and evaluate potential future effects of the removal of sand and gravel from areas of the watershed. Some removal operations may include removal of vegetation and top soil and steepening of slopes. Routine water samples collected monthly in all three watersheds were analyzed for nutrients, organic carbon, major ions, and fecal indicator bacteria. Results of the analyses indicate that, in general, the water quality in all three tributary watersheds is good and meets standards established for drinkingwater supplies for nitrate, but does not always meet contact-recreation standards for bacteria. Median concentrations of total nitrogen, total phosphorus, and total organic carbon were highest in the routine monthly samples from Phelps Brook and lowest from Clear Brook. Samples also were collected during selected storms to examine changes in concentrations of nutrients during periods of high streamflow. The maximum values measured for total nitrogen, total phosphorus, and total organic carbon were in storm samples from Clear Brook.

The Nepaug River watershed delivered the largest loads of total nitrogen, total phosphorus, and total organic carbon to the reservoir. Yields of nutrients and organic carbon differed significantly from year to year and among the three watersheds. Yields of total nitrogen and total organic carbon were largest from Phelps Brook and smallest from Clear Brook. The yields of total phosphorus were largest from Nepaug River and smallest from Phelps Brook. In comparison to other watersheds in Connecticut, annual loads and yields from the three streams were lower than those of developed urban areas and comparable to those of other rural and forested basins. Delivery of nutrients and organic carbon to the reservoir took place mostly during the spring with the exception of those constituents delivered during Tropical Storm Floyd, a large fall storm.

\section{Introduction}

Drinking-water reservoirs in Connecticut face increasing pressure to supply the expanding residential, recreational, and commercial activities of the relatively undeveloped lands that surround them. The Metropolitan District Commission (MDC) monitors and manages land use in the Nepaug Reservoir in northwestern Connecticut, and supplies the City of Hartford and surrounding communities with drinking water. Activities in the watershed that may affect water quality include sand and gravel mining, increased public access, increased residential and commercial development, and changes in forestry practices.

Interest in mining the sand and gravel deposits that underlie parts of the Nepaug Reservoir watershed has increased in recent years. Typical sand and gravel operations, which may affect the landscape and potentially the water quality, include removal of trees, shrubs, and the soil layer, which may be several feet deep; extraction processes, such as washing, sorting, and crushing earth materials; and landscaping and revegetating the mined areas, which may lead to the creation of wetlands, ponds, or lakes. Previous studies of the effects of sand and gravel mining on water quality describe the effects on habitat for aquatic organisms (Waters, 1995; Brown and others, 1998; Femmer, 2002) and how mining may affect ground- and surface-water discharge and quality (Nalley and Haefner, 1999; Stone and others, 2001). Little, if any, empirical evidence has been presented on relations among hydrogeologic changes, surface-water quality, and nutrient transport to downstream watersupply systems.

Despite precautions to maintain current environmental conditions during mining, removal of earth materials can affect hydrologic processes. One direct effect could be that precipitation takes less time to infiltrate the land surface and percolate to the water table. In areas where ground water discharges to a stream, streamflow will likely respond more quickly to precipitation than it did before mining. This rapid hydrologic response has additional implications; for example, dissolved materials such as nutrients may be transported through the subsurface too quickly to allow chemical and biological processes to remove dissolved constituents from the water (biogeochemical transformation and sequestration). Thus, nutrients that surface and soil biota might otherwise incorporate or transform could migrate to the aquifer or stream, and ultimately the reservoir, where these nutrients may contribute to excessive algal growth. Increases in loading of organic carbon to the downstream water supply may increase the potential for the formation of carcinogenic, disinfection by-products (DBPs) during chlorine treatment of drinking water (Reckhow and others, 1990; Aiken and Costaris, 1995; Pomes and others, 1999). Volatile trihalomethane (THM) and halogenated acetic acids compounds (HAA) are recognized 


\section{Surface-Water Quality and Nutrient Loads in the Nepaug Reservoir Watershed, 1999-2001}

DBPs that originate from the chemical disinfection of drinking water. DBPs are a recognized public health risk, carcinogenic to digestive and urinary organs as well as toxic to reproductive and developmental processes. The U.S. Environmental Protection Agency (USEPA) has proposed a maximum contaminant level (MCL) for finished drinking water of 80 micrograms per liter $(\mu \mathrm{g} / \mathrm{L})$ for THM and $60 \mu \mathrm{g} / \mathrm{L}$ for HAA (2006, USEPA List of Drinking Water Contaminants and MCL data accessed September 5, 2006 on the World Wide Web at URL http://www.epa.gov/safewater/mcl.html\#mcls).

In addition to mining sand and gravel, pressure to expand residential and commercial development (currently less than 2 percent) in the watershed has increased recently. Although no large residential subdivisions have been built recently in the watershed, a small number of houses have been built. Increased residential development, with the associated use of lawn and garden fertilizers, can lead to nutrient transport to downstream locations (Novotny and Olem, 1994; Mullaney and Grady, 1997). The introduction of excessive nutrients to a reservoir can lead to algal growth, which in turn can cause taste and odor problems in the public water-supply system. An additional condition-hypoxia — can result as the algae die and decay, depleting the oxygen in the water. This condition may lead to the release of metals and phosphorus from sediments, further affecting water quality (Wetzel, 1983).

In 1997, the U.S. Geological Survey (USGS) and the MDC began a cooperative, three-phase study to evaluate potential effects of sand and gravel mining on streamflow and the quality of water entering Nepaug Reservoir. The first phase of the study was designed to characterize the hydrogeologic framework of the sand and gravel deposits; the results were published in Stone and others (2001). Phase 2 of the study involved additional data collection and interpretation of ground-water level and groundwater-quality data; those results were presented in Mondazzi and Starn (2003). Phase 3 of the study (this report) focuses on surface-water quality, including estimates of nutrient loads to the Nepaug Reservoir from the watershed. An understanding of nutrient and other constituent loads will help the MDC establish a sound scientific relation between land use and potential waterquality changes.

\section{Purpose and Scope}

This report provides information that can be used to evaluate the effects of sand and gravel mining on water quality in the Nepaug Reservoir watershed. It includes data on streamflow and surface-water quality collected in three tributaries to Nepaug Reservoir-Nepaug River, Phelps Brook, and Clear Brook-during water years ${ }^{1} 1999-2001$ (the study period). Water-quality samples were collected monthly (routine samples) and during storms. Loads and yields of nitrogen, phosphorus, and total organic carbon were calculated to determine water-quality constituent loads to the Nepaug Reservoir from its watershed. Historical data, as available, are used to provide a context for the study data.

\section{Previous Studies}

Stone and others (2001) investigated the hydrogeology of the sand and gravel deposits in two areas adjacent to the Nepaug Reservoir. This investigation included the distribution of stratified glacial deposits (gravel, sand, silt, and clay); the thickness and volumes of these materials; the altitude of the water table; the altitude of the bedrock surface; and the potential effects of sand and gravel mining on the physical and chemical responses of the watershed. They estimated that nearly 1 billion cubic feet of sand and gravel, ranging up to approximately 250 feet (ft) thick, is present at four sites near the reservoir. In addition to mapping the geology of the area, Stone and others (2001) described the ground-water hydrology, the effects of sand and gravel deposits on the hydrology, and suggested how local geology may affect biogeochemistry.

Mondazzi and Starn (2003) described the hydrology and quality of ground water in the Nepaug Reservoir watershed, including ground-water-flow direction, hydraulic gradients, and ground-water storage in the North and South areas (fig. 1). Ground-water-quality samples were collected in spring and summer to determine if water quality changes during periods of high and low ground-water levels. Mondazzi and Starn (2003) concluded that the thick coarse-grained deposits have the capacity to store precipitation and release that water slowly to streams, thus reducing high streamflows and increasing low streamflows. They also concluded that as the thickness of the coarse-grained unsaturated deposits increased, a time lag could be seen in the seasonal peaks in ground-water levels (that is, peaks were later in the year).

\section{Description of the Study Area}

The Nepaug Reservoir watershed, including the reservoir, is an area of approximately 32 square miles $\left(\mathrm{mi}^{2}\right)$ in northwestern Connecticut. Three tributaries drain the watershed into the reservoir-Nepaug River, Phelps Brook, and Clear Brook (fig. 1). Two dams, Nepaug Dam and Phelps Dam, impound the streams before they can flow into the Farmington River. The resulting Nepaug Reservoir has an area of 851 acres, with a trophic classification of early mesotrophic based on total phosphorus, chlorophyll-a concentration, and secchi disk measurements (Leland Sanders, Metropolitan District Commission, oral commun., 2000). The reservoir is classified as oligotrophic by the Connecticut Department of Environment Protection (2002, p. F-2). The Nepaug Reservoir watershed is about 86 percent forested land, 10 percent agricultural land, and 2 percent highway corridor (Civco and Hurd, 1990).

\footnotetext{
${ }^{1} \mathrm{~A}$ water year is defined as the 12-month period October 1 through September 30 . The water year is designated by the calendar year in which it ends and which includes 9 of the 12 months. Thus, the year ending September 30, 2001 is called the 2001 water year.
} 


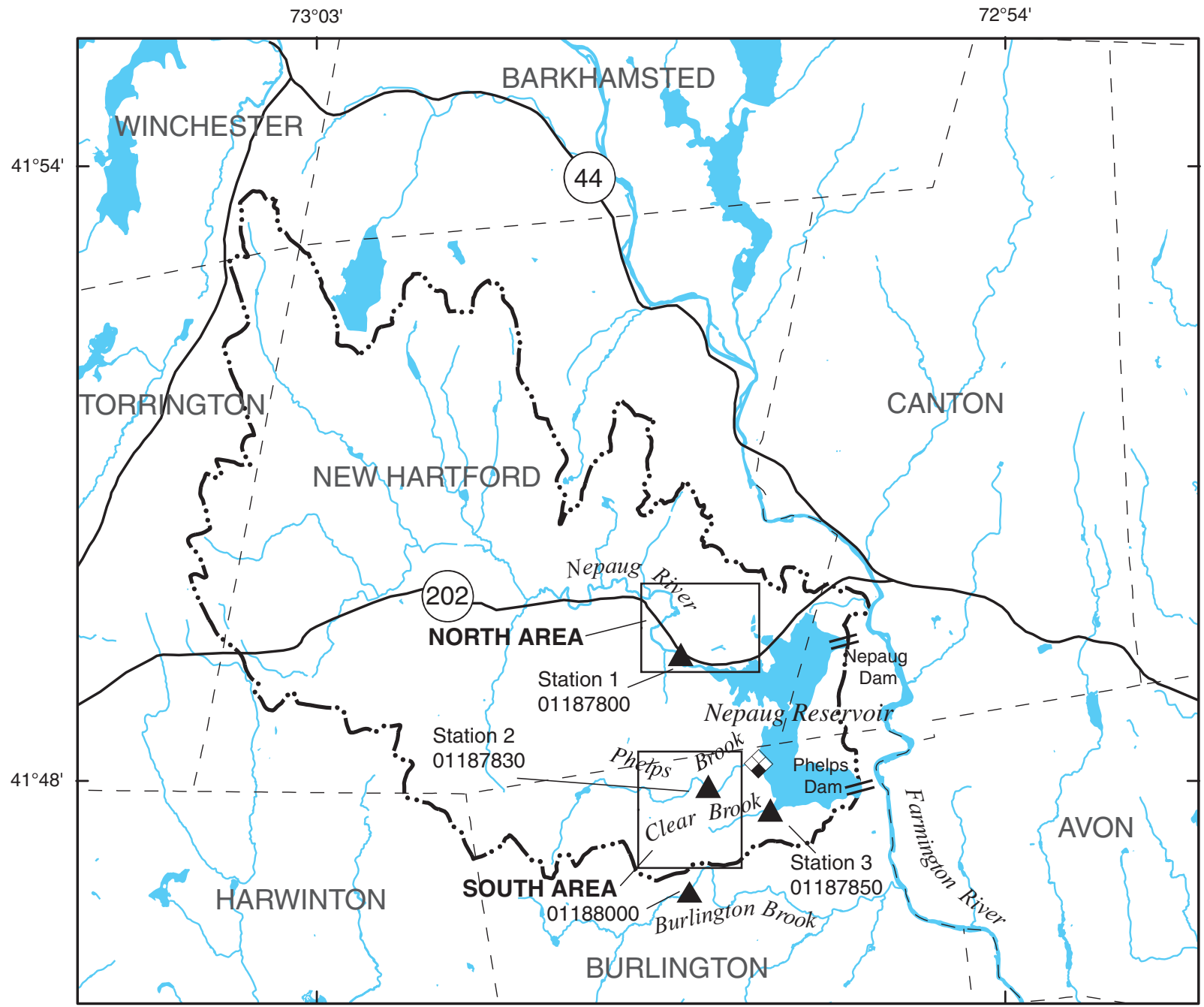

Base from U.S. Geological Survey digital line graphs (1980 and 1988)
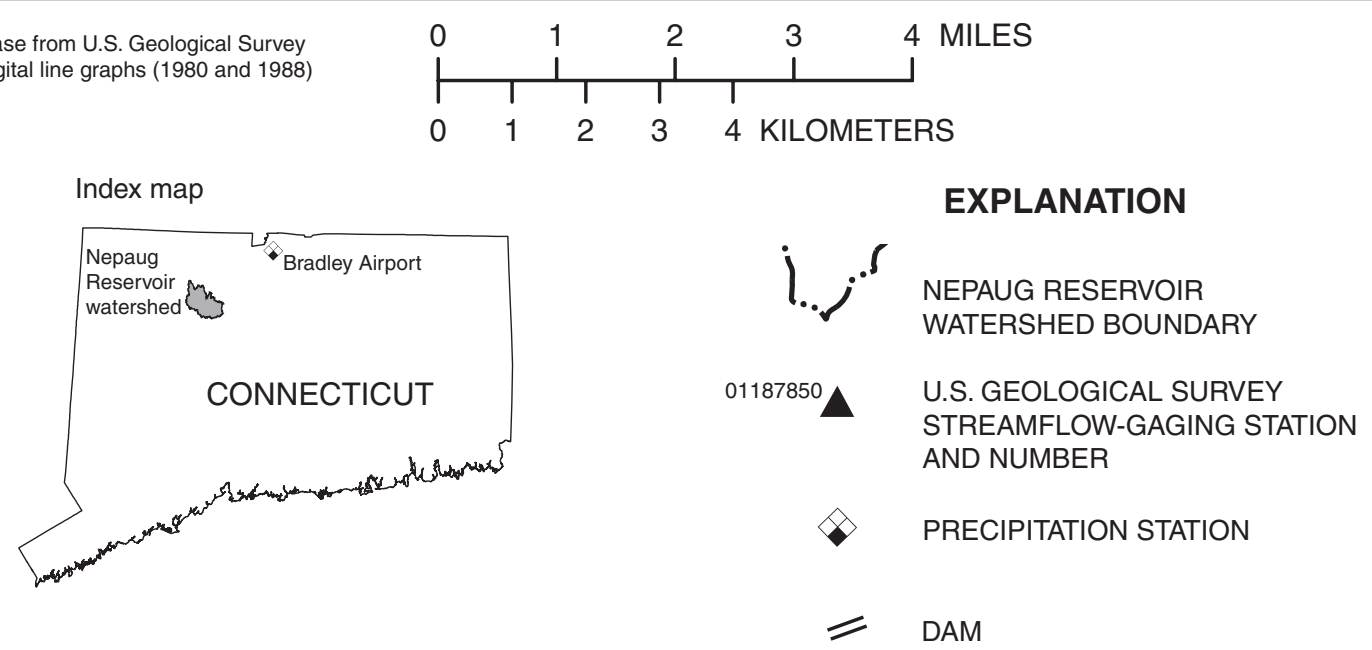

Figure 1. Location of the Nepaug Reservoir watershed and the North and South Areas, northwestern Connecticut. (Modified from Mondazzi and Starn, 2003, fig. 1.) 
The three Nepaug Reservoir tributary watersheds differ in size and extent of development. Nepaug River is the largest tributary, with a drainage area of $23.5 \mathrm{mi}^{2}$ at USGS streamflowgaging station 01187800, Nepaug River near Nepaug, Conn. (table 1). The Nepaug River watershed is sparsely populated, with a population density in the town of New Hartford of 160 persons per square mile, as compared to nearby urbanized Hartford County, which averages 1,158 persons per square mile (data accessed August 24, 2004 on the World Wide Web at URL http://www.census.gov/census2000/states/ct.html).Phelps Brook has a drainage area of $2.7 \mathrm{mi}^{2}$ at USGS streamflow-gaging station 01187830, Phelps Brook at Mill Dam Road near Collinsville, Conn. This watershed contains a few areas of lowdensity residential development in the upper reaches and substantial wetlands created by beaver dams. Clear Brook, the smallest of the three tributaries, has a drainage area of $0.63 \mathrm{mi}^{2}$ at USGS streamflow-gaging station 01187850, Clear Brook near Collinsville, Conn. This watershed lies completely within the MDC property, has no residences, and has minimal wetland areas. MDC currently runs a small-scale sand and gravel mining operation in the Clear Brook watershed. The active sand and gravel operations are confined to 1 to 2 acres in extent. Previous mining operations were in the Phelps Brook watershed and areas north of the Nepaug Reservoir.

\section{Methods of Data Collection and Analysis}

Precipitation, streamflow, and water-quality data were collected during the 3-year study period (1999-2001) using the methods described below. All data are stored in the USGS National Water Information System (NWIS) database.

\section{Precipitation Measurements}

Precipitation data were collected at two National Oceanic and Atmospheric Administration (NOAA) precipitation gages and from a USGS-installed precipitation gage. Long-term precipitation medians and yearly totals were derived from data collected by NOAA at Bradley Airport, Windsor Locks, Conn., about 12 miles (mi) northeast of Nepaug Reservoir. Local storms were characterized by daily precipitation data collected by NOAA at a gage in Burlington, Conn. (fig. 1). Precipitation can vary greatly between Burlington and Bradley Airport because of terrain differences and the track followed by local thunderstorm cells. Also, the Burlington gage could not be used for summary statistics because of missing record on multiple occasions during and prior to the study period. In addition to the NOAA gages, a tipping-bucket precipitation gage was installed at the Phelps Brook streamflow-gaging station to obtain the hourly data necessary to analyze individual storms. The electronic data logger used to record streamflow at Phelps Brook also recorded the hourly precipitation data. Precipitation data were retrieved from the electronic data logger with a laptop computer.

\section{Streamflow Measurements}

Streamflow data were collected on the three tributaries to the Nepaug Reservoir: Nepaug River, Phelps Brook, and Clear Brook (table 1). The Nepaug River station is 0.25 mi upstream from the confluence of the Nepaug River with Nepaug Reservoir; the Phelps Brook station is about 0.5 mi upstream from the confluence of Phelps Brook with Nepaug Reservoir at a bridge crossing on Mill Dam Road near Collinsville, and the Clear Brook station is about $190 \mathrm{ft}$ upstream from the Nepaug Reservoir on Clear Brook Road. All data were collected at 15-minute intervals; however, streamflow data during storms were collected at 5-minute intervals at Clear Brook to obtain better resolution. All streamflow records were computed in accordance with standard USGS protocols for computation of stream-discharge records as described by Rantz and others (1982).

Table 1. U.S. Geological Survey stations in the Nepaug Reservoir watershed used for this study.

[Periods of record are in water years]

\begin{tabular}{|c|c|c|c|c|c|c|c|c|c|}
\hline \multirow{2}{*}{$\begin{array}{l}\text { Station } \\
\text { reference } \\
\text { number } \\
\text { (see fig. 1) }\end{array}$} & \multicolumn{2}{|c|}{ U.S. Geological Survey station } & \multirow{2}{*}{$\begin{array}{l}\text { Drainage } \\
\text { area } \\
\text { (square } \\
\text { miles) }\end{array}$} & \multirow{2}{*}{ Latitude } & \multirow{2}{*}{ Longitude } & \multirow{2}{*}{$\begin{array}{c}\text { Period of } \\
\text { record for } \\
\text { streamflow } \\
\text { measurements }\end{array}$} & \multirow{2}{*}{$\begin{array}{c}\text { Period of } \\
\text { record for } \\
\text { water- } \\
\text { quality } \\
\text { samples }\end{array}$} & \multicolumn{2}{|c|}{$\begin{array}{l}\text { Number of } \\
\text { samples }\end{array}$} \\
\hline & Number & Name & & & & & & Monthly & Storm \\
\hline 1 & 01187800 & $\begin{array}{l}\text { Nepaug River near } \\
\text { Nepaug, Conn. }\end{array}$ & 23.5 & $41^{\circ} 49^{\prime} 14^{\prime \prime}$ & $72^{\circ} 58^{\prime} 14^{\prime \prime}$ & $\begin{array}{l}\text { 1918-1955; } \\
\text { 1958-1972; } \\
1999-2001\end{array}$ & 1999-2001 & 36 & 26 \\
\hline 2 & 01187830 & $\begin{array}{l}\text { Phelps Brook at } \\
\text { Mill Dam Rd. near } \\
\text { Collinsville, Conn. }\end{array}$ & 2.70 & $41^{\circ} 47^{\prime} 59^{\prime \prime}$ & $72^{\circ} 57^{\prime} 56^{\prime \prime}$ & $1999-2001$ & $1999-2001$ & 36 & 14 \\
\hline 3 & 01187850 & $\begin{array}{l}\text { Clear Brook near } \\
\text { Collinsville, Conn. }\end{array}$ & .63 & $41^{\circ} 47^{\prime} 44^{\prime \prime}$ & $72^{\circ} 56^{\prime} 06^{\prime \prime}$ & $\begin{array}{l}\text { 1917-1973; } \\
1999-2001\end{array}$ & $1999-2001$ & 35 & 17 \\
\hline
\end{tabular}




\section{Water-Quality Sampling}

Water samples were collected monthly (routine samples), during storms manually as grab samples, during storms automatically with an autosampler as discrete and composite samples, and with continuous water-quality monitors. All samples were analyzed by the USGS National Water-Quality Lab (NWQL) in Denver, Colorado, and results were published in the annual series of USGS water-data reports (Ranzau and others, 2000; Ranzau and others, 2001; Morrison and others, 2002).

Water samples were collected monthly at the three stations from October 1998 to September 2001. Field parameters, which were measured when each sample was collected, were air and water temperature, dissolved oxygen, $\mathrm{pH}$, specific conductance, turbidity, and alkalinity. The monthly samples were analyzed for concentrations of major ions, nutrients (total and dissolved nitrogen and phosphorus), organic carbon species, and bacteria. All samples for laboratory analysis were collected and processed using methods described by Edwards and Glysson (1988), Wilde and others, (1998a,c) and Wilde and others, (1999a,b); field parameters were measured in accordance with USGS procedures as described by Wilde and Radtke (1998). Samples for bacteriological analysis were collected using methods described by Britton and Greeson (1989).

Additional water samples were collected during storms to provide data for periods of high streamflow. Storm samples also are important for describing constituent concentrations and loads to Nepaug Reservoir. Storm samples were collected at equally spaced time intervals before, during, and after a storm. This is known as time-interval or discrete sampling and was used to ensure the capture of samples during the five distinct parts of the hydrograph: pre-storm, rising limb, peak, falling limb, and post-storm. The sampling time interval was determined by calculating the "lag to peak" - the average lag time between the middle of the storm (center of mass) and the peak in the hydrograph for each stream. The center of mass for selected storms was determined using hourly precipitation data from the Phelps Brook rain gage. The lag to peak was calculated using the following equation (Dingman, 1994, p. 401):

$$
T=2.51 A_{D}^{0.38}
$$

where

$T=$ lag to peak, in hours, and

$A_{D}=$ watershed drainage area, in square kilometers.

The two constants represent the remaining watershed characteristics.

Using this formula resulted in a lag to peak of 11.9 hours for Nepaug River, 5.2 hours for Phelps Brook, and 2.9 hours for Clear Brook. Additional watershed characteristics, such as slope and type of surficial materials, affect the amount and delivery rate of recharge to the streams, and subsequently, the shape of the streamflow hydrograph. In addition to the lag to peak based on size of drainage area, Phelps Brook has a dampened hydrograph peak because of backwater in the wetland areas created by beaver dams. Based on the lag to peak and the shape of the storm hydrograph, the storm-sampling interval used in this study was one water-quality sample per 60 minutes for Nepaug River and Phelps Brook, and one water-quality sample per 15 minutes for Clear Brook. The shorter interval for Clear Brook was used to capture the relatively quick changes in the hydrograph for this smaller watershed.

The size of storm that caused a runoff and hydrograph response of the desired magnitude and duration for each watershed ranged from about 0.1 inch (in.) of rain in less than 6 hours to 2.5 in. of rain in 24 hours. This magnitude and duration, and therefore hydrograph response, was reached most often during rapidly advancing cold fronts that produced a single, shortduration precipitation event. On the basis of these criteria, 10 storms were sampled and analyzed for this study. Storms with more than 2.5 in. of rain in 24 hours or storms of longer duration would have caused extreme hydrograph response in the rate of change and duration of high streamflow and would have exceeded the capacity of the automated sampling equipment.

Discrete and composite samples were collected to determine water quality during storms. Discrete samples are individual samples collected to represent the five parts of the hydrograph (listed above). Discrete samples, collected manually (also called grab samples) or with the autosampler, were analyzed for concentrations of major ions, nutrients (total and dissolved nitrogen and phosphorus), and organic carbon species; this resulted in a data set that can be used to examine nutrient-concentration data as it relates to streamflow. The samples for organic carbon analysis were collected only as grab samples (manually) during field visits because there is no approved protocol for collecting organic carbon samples with the autosampler. Composite samples were created by combining discrete samples proportionally according to streamflow. Composite samples were analyzed as one sample for concentrations of major ions and nutrients (total and dissolved nitrogen and phosphorus); this procedure resulted in a single, discharge-weighted concentration value that was used to calculate constituent loads.

Continuous water-quality monitors were used to measure and record water temperature, specific conductance, $\mathrm{pH}$, dissolved oxygen, and turbidity at 15-minute intervals. Electronic multi-parameter monitors were installed in the gage pool at each of the three stations to record the rapidly changing water quality during runoff events in the spring, summer, and fall. Some continuous water-quality-monitoring data coincided with storm samples, but several storms had only continuous monitor data when no water samples were collected. All procedures relating to water-quality monitors (calibration, maintenance, record computation, storage, and archiving) are described by Wagner and others (2000). 


\section{Surface-Water Quality and Nutrient Loads in the Nepaug Reservoir Watershed, 1999-2001}

\section{Water-Quality Data Analysis}

Summary statistics of monthly water-quality data were computed using the S-PLUS statistical package (Insightful, 2000). Minimum, median, and maximum concentration values for each constituent were used to compare the water-quality characteristics of the three tributary watersheds.

Due to non-normal distribution of data for fecal coliform and enterococci bacteria, a nonparametric statistical procedure was used to determine differences between station medians. The procedure used, the Wilcoxon rank-sum test (Helsel and Hirsch, 2002), compares the ranks within each data set by station. Also, because of the positively skewed bacteria data, the mean of the logarithms transformed back to their original units (the geometric mean) was reported. The geometric mean of the bacteria data at each station was used to summarize the data and to compare with the state of Connecticut water-quality standards for Class B waters (contact recreation).

\section{Load Estimation}

The stream load of a constituent is the amount or quantity of the constituent transported by the stream in a given length of time, such as the annual load for a water year or the instantaneous load during a storm. Annual constituent loads for nitrogen, phosphorus, and organic carbon entering Nepaug Reservoir from each tributary were estimated by using daily mean streamflow and water-quality data collected during this study. Nutrient loads were calculated from the three tributary watersheds using the USGS LOADEST program. This program was described in detail by Runkel and others (2004). The LOADEST models were then examined for goodness of fit, and the models with the best fit were chosen. Load models were selected on the basis of the rank of the Akaike Information Criterion test statistic (Runkel and others, 2004, p. 7). The models were run with and without the storm and composite sampling data. Several discrete samples from each of the three watersheds were not used in the load models. These deleted samples were typically from the post-peak part of the streamflow hydrographs and contributed significant error to model calculations, including the prediction of negative loads.

Constituent loads based on data from the monthly samples were estimated by the rating-curve (regression) method (Cohn and others, 1989; Crawford, 1991). Because some constituent concentrations were less than the detection limit, parameters of the rating curve were estimated by maximum-likelihood methods (Dempster and others, 1977; Wolynetz, 1979) or the linearattribution method (Chatterjee and McLeash, 1986). Estimates of the uncertainties in the load estimates were determined using the methods described by Likes (1980) and Gilroy and others (1990) for maximum-likelihood estimates and by the jackknife method (Efron, 1982) for linear-attribution estimates. A detailed description of these statistical methods may be found in Crawford (1996).

Estimates of mean daily loads with confidence intervals were selected from several regression models after first analyz- ing each regression for the best fit to the data using S-PLUS (Insightful, 2000). Confidence intervals are a measure of the expected difference between the model prediction and the true load at a site, and represent both model uncertainty and natural sample variability. Estimated monthly and annual mean daily loads, in units of pounds per day, were calculated for each water year along with the standard error and standard error of prediction for each mean daily load estimate. Estimated total annual loads of total nitrogen, total phosphorus, and total organic carbon were used to compute the total yield for each watershed.

A mass-integration method was used to calculate storm loads, which are highly variable in a short time period. Instantaneous storm loads were calculated for the pre-storm, rising limb, peak, falling limb, and post-storm parts of the hydrograph. The instantaneous loads were calculated by subdividing the day into time blocks and multiplying the instantaneous concentration by the instantaneous streamflow and a factor to convert from milligrams per liter to pounds per cubic foot for the time blocks. The values for each time block were then added together to compute the load for the day. The instantaneous storm loads were "integrated" for a 24 -hour period to represent a total daily load. The integrated storm loads were compared to the daily loads from the regression analysis to evaluate whether the regression method could be used to compute storm loads in small watersheds (less than $100 \mathrm{mi}^{2}$ in area). The more laborintensive integration method was believed to give a better estimate than the regression method because of the use of several concentration values recorded throughout the storm hydrograph. The regression estimate used one monthly concentration and the average daily streamflow, ultimately leading to loss of sensitivity to hourly flow and associated concentration changes that could be important in smaller watersheds. The regression method is recommended for yearly or possibly seasonal load estimates. Daily values calculated with the regression method were used only for comparison to the integration method and are not reported here.

\section{Precipitation, Streamflow, and Runoff in the Nepaug Reservoir Watershed}

Summary statistics derived from long-term precipitation data (1905-2001) at Bradley Airport (National Oceanic and Atmospheric Administration, 1998-2001) are given in table 2. Water year 1999 was extremely dry until Tropical Storm Floyd entered Connecticut on September 16, 1999, bringing rainfall amounts in excess of 9 in. to some areas in western and central Connecticut (Ranzau and others, 2000). Precipitation returned to more normal levels in water year 2000. This was followed by a drought in the 2001 water year, which had less precipitation than any year in the preceding 60 years of record. Local precipitation data at Burlington were available to characterize storms (fig. 2). Although it appears on figure 2 that precipitation was evenly distributed throughout the study period, a closer examination of the graph shows that the summer months had atypical precipitation patterns. 
Table 2. Precipitation data used for this study.

\begin{tabular}{llc}
\hline \multicolumn{1}{c}{ Time period } & $\begin{array}{c}\text { Precipitation at } \\
\text { Bradley Airport } \\
\text { (inches/year) }\end{array}$ & $\begin{array}{c}\text { Departure from } \\
\text { 30-year } \\
\text { reference } \\
\text { period } \\
\text { (1972-2001) } \\
\text { (inches) }\end{array}$ \\
\hline Water year 1999 & 43.40 & -2.88 \\
Water year 2000 & 46.40 & .12 \\
Water year 2001 & 34.53 & -11.75 \\
\hline $\begin{array}{l}\text { Median for the 30-year } \\
\text { reference period (1972-2001) }\end{array}$ & 46.28 & \\
$\begin{array}{l}\text { Median for the period of record } \\
\text { (1905-2001) }\end{array}$ & 42.60 & \\
\hline
\end{tabular}

Streamflow and runoff during the study period also varied considerably, both from year to year and from station to station (table 3). Variability in streamflow ranged over three orders of magnitude at Nepaug River, over four orders of magnitude at Phelps Brook, and over one order of magnitude at Clear Brook (figs. 3A-C). Peak instantaneous discharges, as a result of Tropical Storm Floyd, were approximately 2,100 cubic feet per second $\left(\mathrm{ft}^{3} / \mathrm{s}\right)$ at Nepaug River, $790 \mathrm{ft}^{3} / \mathrm{s}$ at Phelps Brook, and 27 $\mathrm{ft}^{3} / \mathrm{s}$ at Clear Brook (Ranzau and others, 2000). The low and the high daily mean streamflows at Clear Brook are moderated by the extensive glacial stratified deposits underlying this watershed. resulting in less or limited change in streamflow seasonally or during a hydrologic event such as a storm.

Runoff also was variable from station to station. Clear Brook had 38.8 in. of mean annual runoff for the study period, compared to 23.9 in. for Phelps Brook and 24.6 in. for Nepaug River. The greater runoff from Clear Brook is apparent upon comparison of the three unit hydrographs (figs. 4A-B). A unit hydrograph represents normalized streamflow, which is obtained by dividing the mean daily streamflow by the drainage area, measured in cubic feet per second per square mile.

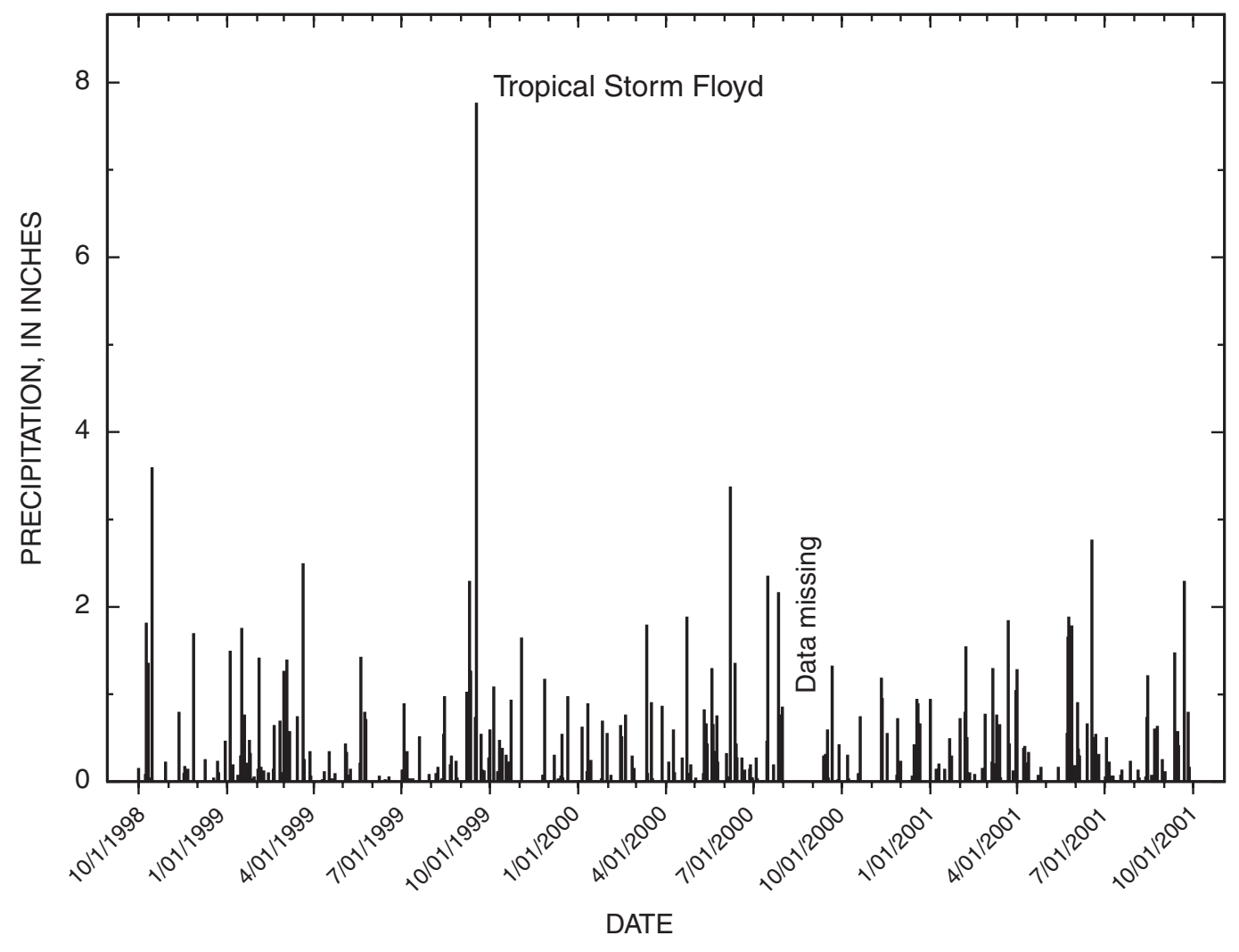

Figure 2. Precipitation at Burlington, Connecticut, water years 1999-2001. 
Table 3. Statistical summary of surface-water data for U.S. Geological Survey stations in the Nepaug Reservoir watershed, water years 1999-2001.

[--, not applicable $]$

\begin{tabular}{|c|c|c|c|c|c|}
\hline Water year & $\begin{array}{l}\text { Annual total mean } \\
\text { discharge } \\
\text { (cubic feet per } \\
\text { second) }\end{array}$ & $\begin{array}{l}\text { Highest daily mean } \\
\text { discharge } \\
\text { (cubic feet per } \\
\text { second) }\end{array}$ & $\begin{array}{l}\text { Lowest daily mean } \\
\text { discharge } \\
\text { (cubic feet per } \\
\text { second) }\end{array}$ & $\begin{array}{c}\text { Annual runoff } \\
\text { (inches) }\end{array}$ & $\begin{array}{c}\text { Annual runoff } \\
\text { (cubic feet per } \\
\text { second per } \\
\text { square mile) }\end{array}$ \\
\hline \multicolumn{6}{|c|}{ Station 01187800 Nepaug River near Nepaug, Connecticut } \\
\hline 1999 & 13,900 & 959 & 2.3 & 22.0 & 1.62 \\
\hline 2000 & 17,300 & 523 & 7.1 & 27.4 & 2.01 \\
\hline 2001 & 15,300 & 545 & 3.8 & 24.3 & 1.79 \\
\hline Mean & 15,500 & -- & -- & 24.6 & 1.81 \\
\hline \multicolumn{6}{|c|}{ Station 01187830 Phelps Brook at Mill Dam Rd. near Collinsville, Connecticut } \\
\hline 1999 & 1,420 & 139 & 0.03 & 19.5 & 1.44 \\
\hline 2000 & 1,820 & 63 & .85 & 25.1 & 1.84 \\
\hline 2001 & 1,970 & 60 & .11 & 27.2 & 2.00 \\
\hline Mean & 1,740 & -- & -- & 23.9 & 1.76 \\
\hline \multicolumn{6}{|c|}{ Station 01187850 Clear Brook near Collinsville, Connecticut } \\
\hline 1999 & 550 & 8.2 & 0.90 & 34.7 & 2.55 \\
\hline 2000 & 677 & 4.0 & 1.1 & 42.7 & 3.13 \\
\hline 2001 & 620 & 5.5 & .98 & 39.1 & 2.88 \\
\hline Mean & 616 & -- & -- & 38.8 & 2.85 \\
\hline
\end{tabular}

Normalized streamflow for Clear Brook (figs. 4A-B) was consistently higher after periods of peak streamflow, with less seasonal variation than the other two tributaries. This observation is consistent with the finding by Mondazzi and Starn (2003) that the surface-water drainage area (topographic drainage area) of Clear Brook is smaller than the ground-water drainage area (contributing area). This would mean that the ground-water contribution to streamflow is larger in Clear Brook, and it can sustain streamflow levels during prolonged dry periods. Runoff from both Nepaug River and Clear Brook decreased more than 3 in. from water year 2000 to water year 2001, along with the decrease in precipitation. Runoff at Phelps Brook, however, was approximately $2 \mathrm{in}$. more during the 2001 water year than the 2000 water year. This could be due to the gradual release of water stored in the beaver ponds and associated wetlands that were constructed upstream from the streamflow-gaging station during 2000 and 2001.

Flow-duration curves represent the percentage of time that a given streamflow is equaled or exceeded. The distribution of daily mean streamflow during the study period matched or slightly exceeded the distributions of daily mean streamflow for water years 1922-2001 at Nepaug River (fig. 5A) and Clear Brook (fig. 5C). A comparison of the shapes of the flow-duration curves for the three stations shows that Nepaug River and Phelps Brook have similar shapes and flow distributions; how- ever, the curve shape and flow distribution for Clear Brook appears much different (figs. 5A-5C). The flow-duration curves for the three stations, normalized for drainage area, indicate that streamflow extremes in Clear Brook were buffered for the period of record and the study period (figs. 5A-C). The result was less departure from normal streamflow in magnitude and duration during low- and high-flow events.

\section{Surface-Water Quality in the Nepaug Reservoir Watershed}

Data from the routine monthly water samples show that water quality in the Nepaug Reservoir watershed is generally good and meets standards established for drinking-water supply for nitrate, but does not always meet contact-recreation standards for bacteria. Although the three tributaries differ in size, base streamflow, and land uses, concentrations of most dissolved constituents were low and indicate a largely natural, forested watershed with few indicators of human activity. Results of the monthly water sampling are discussed by constituent in this section of the report. Summary statistics for water-quality constituents are presented in table 4. 

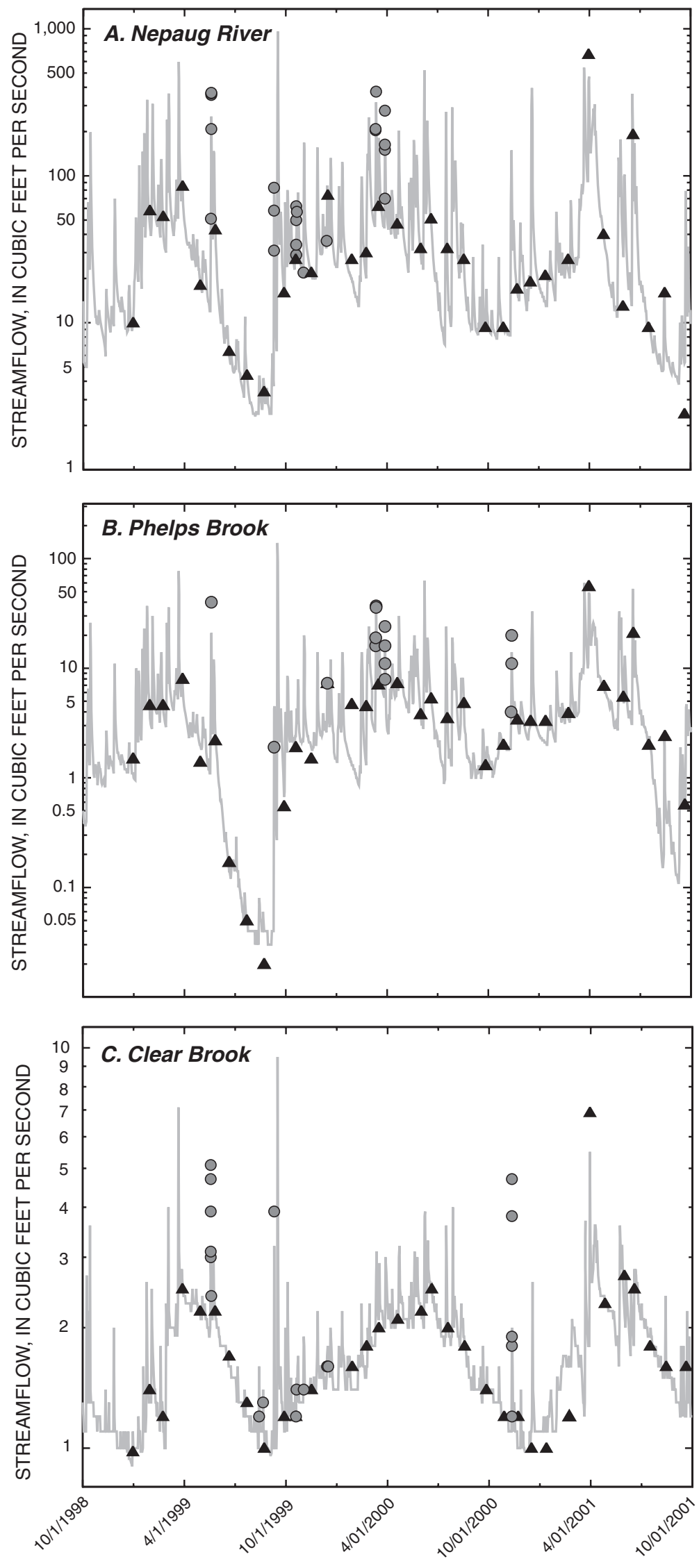

DATE

\section{EXPLANATION}

- DAILY MEAN STREAMFLOW

- INSTANTANEOUS STREAMFLOW DURING MONTHLY WATER-QUALITY-SAMPLE COLLECTION

- INSTANTANEOUS STREAMFLOW DURING STORM-SAMPLE COLLECTION

Figure 3. Streamflow at three U.S. Geological Survey stations indicating dates and flow conditions when water samples were collected, water years 1999-2001: $A$, station 01187800 Nepaug River near Nepaug, Connecticut; $B$, station 01187830 Phelps Brook near Collinsville, Connecticut; and $C$, station 01187850 Clear Brook near Collinsville, Connecticut. 

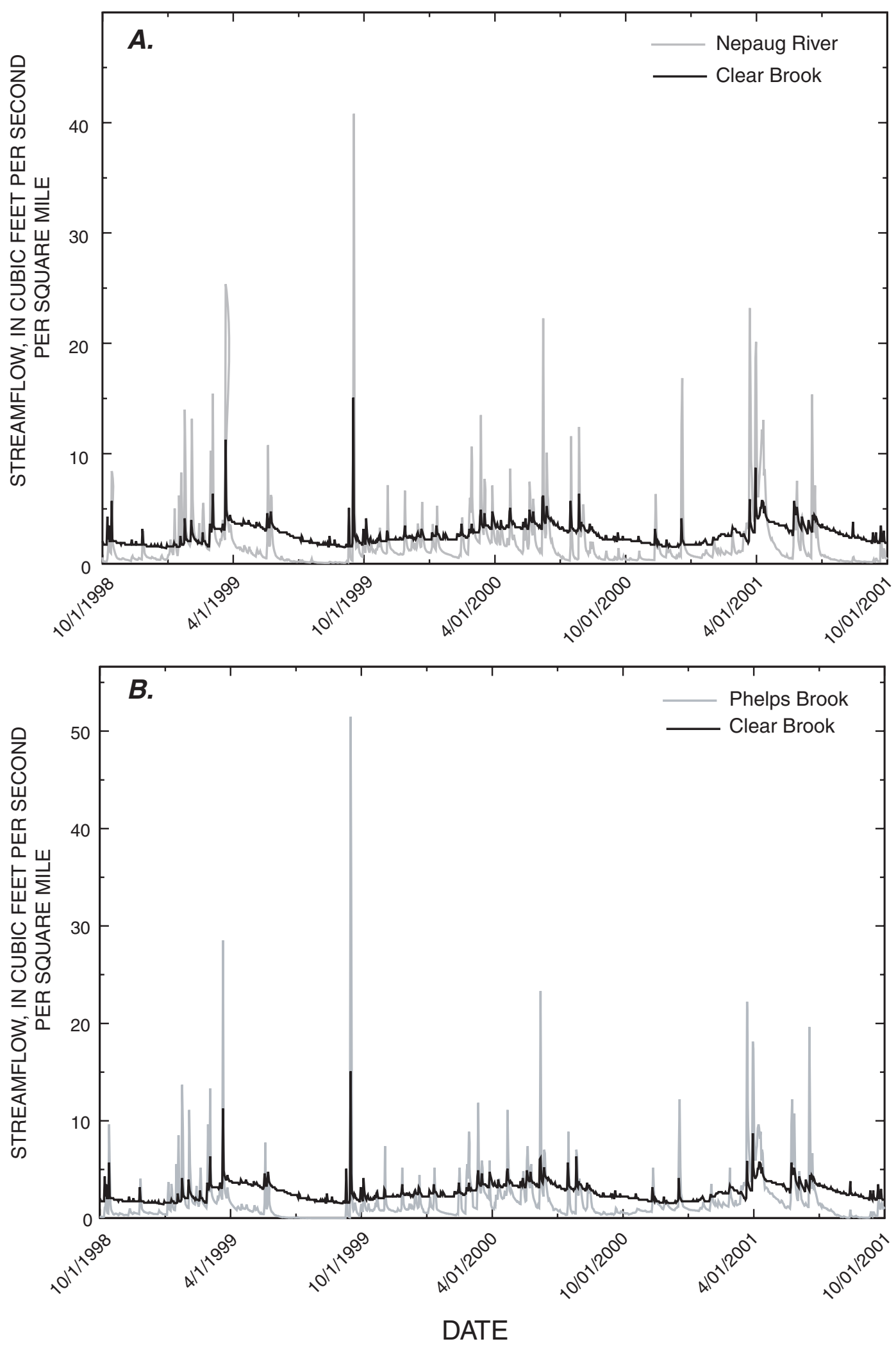

Figure 4. Streamflow in A, Nepaug River and Clear Brook; and B, Phelps Brook and Clear Brook, adjusted by size of drainage basin, for water years 1999-2001. 

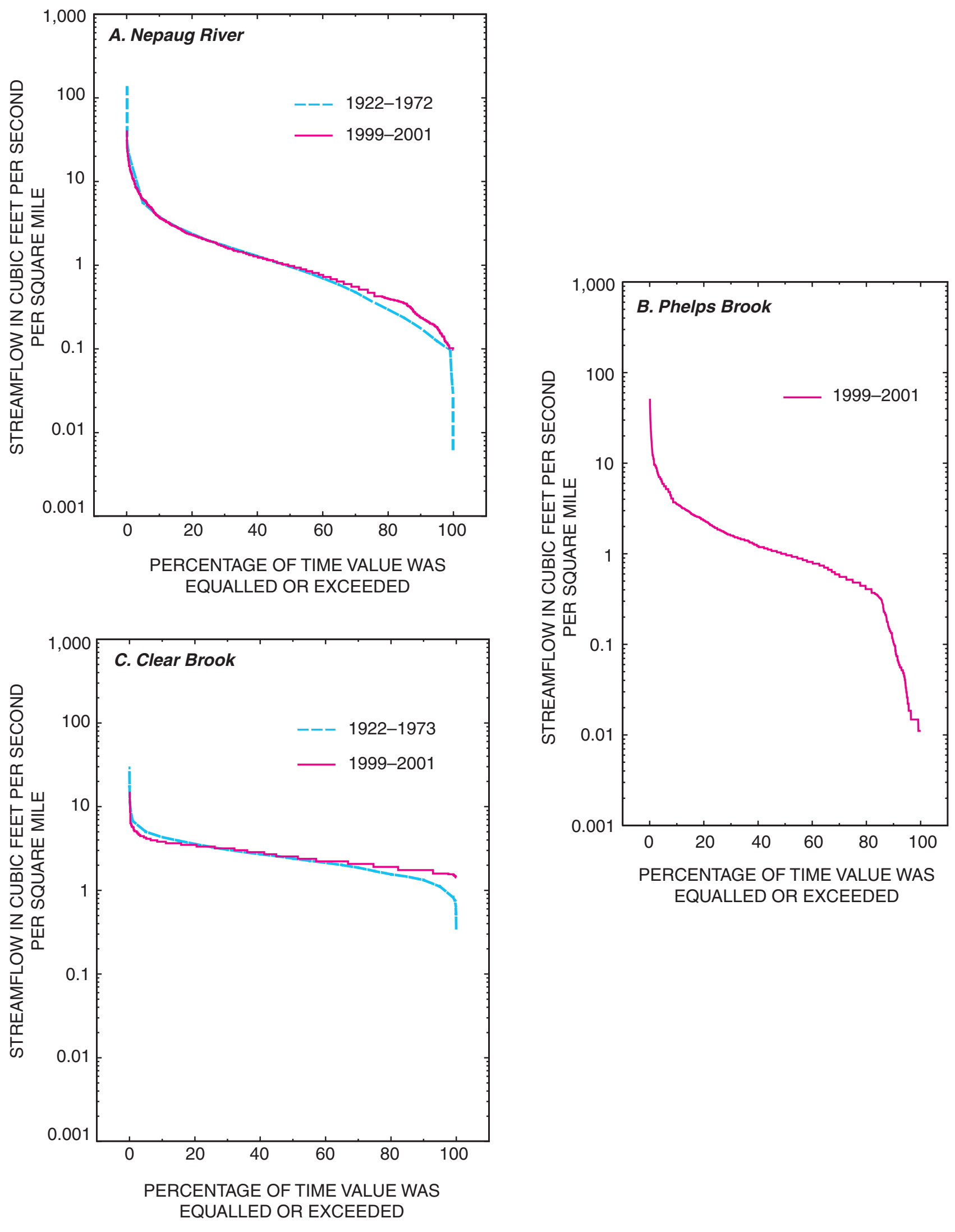

Figure 5. Flow-duration curve showing streamflow normalized by drainage area at three U.S. Geological Survey stations during the study period and the long-term period of record: $A$, station 01187800 Nepaug River near Nepaug, Connecticut; $B$, station 01187830 Phelps Brook near Collinsville, Connecticut; and $C$, station 01187850 Clear Brook near Collinsville, Connecticut. 
Table 4. Statistical summary of monthly water-quality data for U.S. Geological Survey stations in the Nepaug Reservoir watershed, water years $1999-2001$.

$\left[\mathrm{ft}^{3} / \mathrm{s}\right.$, cubic foot per second; NTU, nephelometric turbidity units; $\mu \mathrm{s} / \mathrm{cm}$ at $25^{\circ} \mathrm{C}$, microsiemens per centimeter at 25 degrees Celsius; $\mathrm{mg} / \mathrm{L}, \mathrm{milligrams}$ per liter; $\mu \mathrm{g} / \mathrm{L}$, micrograms per liter; $\mathrm{N}$, nitrogen; $\mathrm{P}$, phosphorus; $\mathrm{Ca}$, calcium; $\mathrm{Mg}$, magnesium; $\mathrm{Na}$, sodium; $\mathrm{K}$, potassium; $\mathrm{Cl}$, chloride; $\mathrm{SO}_{4}$, sulfate; $\mathrm{F}$, fluoride; $\mathrm{SiO}_{2}$, silicon dioxide; $\mathrm{Fe}$, iron; $\mathrm{Mn}$, manganese; col/100 mL, colonies per 100 milliliters; <, less than; E, estimated; $\mathrm{k}$, non-ideal colony count]

\begin{tabular}{|c|c|c|c|c|c|c|c|c|c|}
\hline \multirow[t]{2}{*}{ Water-quality property or constituent (units) } & \multicolumn{3}{|c|}{$\begin{array}{c}\text { Nepaug River near Nepaug } \\
01187800\end{array}$} & \multicolumn{3}{|c|}{$\begin{array}{c}\text { Phelps Brook at Mill Dam Rd. at } \\
\text { Collinsville } \\
01187830\end{array}$} & \multicolumn{3}{|c|}{$\begin{array}{c}\text { Clear Brook near Collinsville } \\
01187850\end{array}$} \\
\hline & Minimum & Median & Maximum & Minimum & Median & Maximum & Minimum & Median & Maximum \\
\hline \multicolumn{10}{|c|}{ PHYSICAL AND CHEMICALLY RELATED PROPERTIES } \\
\hline Discharge, instantaneous $\left(\mathrm{ft}^{3} / \mathrm{s}\right)$ & 2.4 & 24 & 671 & 0.02 & 3.4 & 56 & 0.98 & 1.6 & 6.9 \\
\hline Turbidity (NTU) & .50 & 1.0 & 15 & .78 & 1.2 & 4.5 & .21 & .50 & 12 \\
\hline Oxygen, dissolved (mg/L) & 7.7 & 10.6 & 15.3 & 6.9 & 10.2 & 13.9 & 9.2 & 11.4 & 13.6 \\
\hline pH (standard units) & 5.8 & 6.9 & 7.8 & 5.7 & 6.6 & 6.9 & 5.8 & 6.9 & 7.2 \\
\hline Specific conductance $\left(\mu \mathrm{s} / \mathrm{cm}\right.$ at $\left.25^{\circ} \mathrm{C}\right)$ & 61 & 86 & 141 & 47 & 72 & 113 & 34 & 43 & 76 \\
\hline Alkalinity, dissolved (mg/L as $\mathrm{CaCO}_{3}$ ) & 3 & 10 & 26 & 2 & 6 & 13 & 4 & 7 & 15 \\
\hline \multicolumn{10}{|c|}{ MAJOR INORGANIC CONSTITUENTS } \\
\hline Calcium, dissolved (mg/L as Ca) & 2.4 & 5.0 & 6.8 & 2.2 & 3.0 & 4.9 & 1.7 & 2.4 & 2.8 \\
\hline Magnesium, dissolved (mg/L as $\mathrm{Mg}$ ) & .89 & 1.9 & 2.4 & .88 & 1.9 & 2.4 & .70 & 1.0 & 1.1 \\
\hline Sodium, dissolved (mg/L as $\mathrm{Na}$ ) & 5.4 & 7.6 & 14 & 3.8 & 6.7 & 12 & 2.5 & 3.2 & 3.9 \\
\hline Potassium, dissolved (mg/L as $\mathrm{K})$ & .64 & .94 & 2.6 & .47 & 1.0 & 1.8 & .55 & .66 & .85 \\
\hline Chloride, dissolved (mg/L as $\mathrm{Cl}$ ) & 7.1 & 12 & 24 & 4.2 & 11 & 19 & 2.5 & 3.6 & 6.1 \\
\hline Sulfate, dissolved (mg/L as $\mathrm{SO}_{4}$ ) & 4.3 & 6.7 & 9.6 & 3.5 & 6.4 & 12 & 3.9 & 5.2 & 6.0 \\
\hline Fluoride, dissolved (mg/L as F) & $<.10$ & $<.10$ & .60 & $<.10$ & $<.10$ & .40 & $<.10$ & $<.10$ & $<.20$ \\
\hline Silica, dissolved (mg/L as $\mathrm{SiO}_{2}$ ) & 4.2 & 9.4 & 11 & 2.0 & 6.4 & 11 & 5.8 & 11 & 12 \\
\hline
\end{tabular}


Table 4. Statistical summary of monthly water-quality data for U.S. Geological Survey stations in the Nepaug Reservoir watershed, water years 1999-2001.-Continued

$\left[\mathrm{ft}^{3} / \mathrm{s}\right.$, cubic foot per second; NTU, nephelometric turbidity units; $\mu \mathrm{s} / \mathrm{cm}$ at $25^{\circ} \mathrm{C}$, microsiemens per centimeter at 25 degrees Celsius; $\mathrm{mg} / \mathrm{L}$, milligrams per liter; $\mu \mathrm{g} / \mathrm{L}$, micrograms per liter; $\mathrm{N}$, nitrogen; $\mathrm{P}$, phosphorus; $\mathrm{Ca}$, calcium; $\mathrm{Mg}$, magnesium; $\mathrm{Na}$, sodium; $\mathrm{K}$, potassium; $\mathrm{Cl}$, chloride; $\mathrm{SO}_{4}$, sulfate; $\mathrm{F}$, fluoride; $\mathrm{SiO}_{2}$, silicon dioxide; $\mathrm{Fe}$, iron; $\mathrm{Mn}$, manganese; col/100 $\mathrm{mL}$, colonies per 100 milliliters; <, less than; E, estimated; $\mathrm{k}$, non-ideal colony count]

\begin{tabular}{|c|c|c|c|c|c|c|c|c|c|}
\hline \multirow[t]{2}{*}{ Water-quality property or constituent (units) } & \multicolumn{3}{|c|}{$\begin{array}{c}\text { Nepaug River near Nepaug } \\
01187800\end{array}$} & \multicolumn{3}{|c|}{$\begin{array}{c}\text { Phelps Brook at Mill Dam Rd. at } \\
\text { Collinsville } \\
01187830\end{array}$} & \multicolumn{3}{|c|}{$\begin{array}{c}\text { Clear Brook near Collinsville } \\
01187850\end{array}$} \\
\hline & Minimum & Median & Maximum & Minimum & Median & Maximum & Minimum & Median & Maximum \\
\hline \multicolumn{10}{|c|}{ NITROGEN, PHOSPHORUS, AND CARBON } \\
\hline Nitrogen, ammonia + organic, dissolved $(\mathrm{mg} / \mathrm{L}$ as $\mathrm{N})$ & E 0.06 & 0.14 & 0.38 & 0.11 & 0.24 & 0.52 & E 0.05 & 0.10 & 0.15 \\
\hline $\begin{array}{l}\text { Nitrogen, ammonia + organic, total }(\mathrm{mg} / \mathrm{L} \text { as } \mathrm{N}) \\
\text { (Kjeldahl nitrogen) }\end{array}$ & E.08 & .18 & .66 & .17 & .34 & 1.0 & E.04 & .10 & .84 \\
\hline Nitrite + nitrate, dissolved (mg/L as $\mathrm{N})$ & .05 & .12 & .32 & E.03 & .065 & .31 & E.04 & $<.05$ & .11 \\
\hline Nitrogen, total $(\mathrm{mg} / \mathrm{L} \text { as } \mathrm{N})^{1}$ & .16 & .34 & .79 & .25 & .43 & 1.0 & .05 & .11 & .94 \\
\hline Phosphorus, dissolved (mg/L as $\mathrm{P}$ ) & E.003 & .007 & .023 & E.004 & .009 & .021 & E.003 & .004 & .007 \\
\hline Phosphorus, total (mg/L as $\mathrm{P})$ & .004 & .013 & .131 & .008 & .020 & .053 & .004 & .007 & .081 \\
\hline Organic carbon, particulate (mg/L as $\mathrm{C}$ ) & $<.2$ & $<.2$ & .3 & $<.2$ & .2 & .5 & $<.2$ & .2 & .4 \\
\hline Organic carbon, dissolved (mg/L as $\mathrm{C}$ ) & 1.8 & 2.5 & 5.2 & 1.7 & 3.3 & 7.7 & .6 & .9 & 1.4 \\
\hline Organic carbon, total (mg/L as $\mathrm{C}$ ) & 1.7 & 3.2 & 8.9 & 1.1 & 6.1 & 13 & 1.0 & 1.4 & 11 \\
\hline \multicolumn{10}{|c|}{ TRACE METALS } \\
\hline Iron, dissolved ( $\mu \mathrm{g} / \mathrm{L}$ as $\mathrm{Fe})$ & 47 & 110 & 350 & 70 & 290 & 650 & 5 & 13 & 50 \\
\hline Manganese, dissolved ( $\mu \mathrm{g} / \mathrm{L}$ as $\mathrm{Mn})$ & 6.7 & 19 & 38 & 17 & 46 & 140 & 1.4 & 2.1 & 5.8 \\
\hline \multicolumn{10}{|c|}{ BACTERIA } \\
\hline Fecal coliform (col/100 mL) & $<1$ & 23 & $1,100 \mathrm{k}$ & $<1$ & 21 & $784 \mathrm{k}$ & $<1$ & 7.5 & $70 \mathrm{k}$ \\
\hline Enterococci coliform (col/100 mL) & $2 \mathrm{k}$ & 31.5 & $863 \mathrm{k}$ & $1 \mathrm{k}$ & 10.5 & $668 \mathrm{k}$ & $<1$ & 11 & $109 \mathrm{k}$ \\
\hline
\end{tabular}

${ }^{1}$ Calculated by method described in Mullaney and others (2002). 


\section{Physical and Chemically Related Properties}

The following physical and chemically related properties were measured: turbidity, dissolved oxygen, $\mathrm{pH}$, specific conductance, and alkalinity. In general, the physical parameters indicate low ionic-strength, well oxygenated water, similar to the ground-water quality described by Mondazzi and Starn (2003). The slightly acidic pH values for most monthly water samples for the three stations are likely the result of the lack of buffering capacity of the watershed as indicated by low measured alkalinities. Median alkalinity values for the three streams were less than or equal to 10 milligrams per liter $(\mathrm{mg} / \mathrm{L})$ as $\mathrm{CaCO}_{3}$. The median specific conductance values at Clear Brook (43 microsiemens per centimeter $(\mu \mathrm{S} / \mathrm{cm}))$, Nepaug River $(86$ $\mu \mathrm{S} / \mathrm{cm})$ and Phelps Brook $(72 \mu \mathrm{S} / \mathrm{cm})$ are characteristic of low ionic-strength water draining silicate geologic terrain.

Nepaug River and Phelps Brook watersheds have similar water-quality characteristics, whereas the water from Clear Brook differs somewhat in physical and chemical characteristics. During routine monthly sampling, Clear Brook had lower concentrations of both dissolved and suspended constituents, and concentrations showed little variation. Water quality in Clear Brook is most similar to that of the ground water in the watershed (Mondazzi and Starn, 2003, p. 20-23), whereas the quality of water from Nepaug River and Phelps Brook is more typical of surface runoff from forested and rural residential watersheds, such as Burlington Brook (USGS streamflow-gaging station 01188000) (fig. 1).

\section{Major Inorganic Constituents}

The low variability in the concentrations of major inorganic constituents in Clear Brook reflects the large part of streamflow that is derived from ground-water discharge into the brook. The stable relation between specific conductance and ionic concentrations supports using continuously measured specific conductance as a surrogate for major ions at this station.

Nepaug River and Phelps Brook, however, showed variability in major ion concentration during routine monthly sampling. Several public roads cross these two watersheds, and the application of deicing salt in winter probably accounts for the relatively high concentrations of chloride. The highest measured chloride concentration was in a sample from the Nepaug River watershed (24 mg/L, December 15, 2000) where potential sources of chloride - road salt, septic effluent, and agricultural wastes - are more common. In contrast, the maximum concentration of chloride in Clear Brook $(6.1 \mathrm{mg} / \mathrm{L})$ was lower than nearly all the chloride measurements in the other two watersheds. Despite having higher chloride concentrations than Clear Brook, the maximum chloride concentrations in the Nepaug River watershed are lower than those found in other watersheds in Connecticut that have similar land uses and public roads; those watersheds typically have chloride concentrations of 100 mg/L (J.R. Mullaney, U.S. Geological Survey, oral commun., 2005).
Silica concentrations also differ among the three watersheds. Median concentrations of silica were higher in Clear Brook $(11 \mathrm{mg} / \mathrm{L})$ than in Phelps Brook $(6.4 \mathrm{mg} / \mathrm{L})$ or Nepaug River $(9.4 \mathrm{mg} / \mathrm{L})$. The higher concentrations of silica in Clear Brook may be from ground water draining sandy soils and surficial materials, whereas Phelps Brook and Nepaug River have proportionally less ground-water contribution and more stream cobbles and wetlands in their headwaters.

\section{Nitrogen, Phosphorus, and Organic Carbon}

Median concentrations of total nitrogen and total phosphorus in Nepaug River and Phelps Brook (table 4) were generally low and were similar to total nitrogen and total phosphorus concentrations $(0.26$ and $0.022 \mathrm{mg} / \mathrm{L})$ reported for undeveloped stream basins of the United States during calendar years 19901995 (Clark and others, 2000). The median concentrations of total nitrogen and total phosphorus during the study period in nearby Burlington Brook were comparable at 0.46 and 0.009 $\mathrm{mg} / \mathrm{L}$, respectively (Ranzau and others, 2000; Ranzau and others, 2001; Morrison and others, 2002). Median concentrations of total nitrogen and total phosphorus in Clear Brook were lower (0.11 and $0.007 \mathrm{mg} / \mathrm{L}$, respectively). Phelps Brook had the highest median total Kjeldahl nitrogen $(0.34 \mathrm{mg} / \mathrm{L})$, median total nitrogen $(0.43 \mathrm{mg} / \mathrm{L})$, median total phosphorus $(0.020$ $\mathrm{mg} / \mathrm{L})$, and median total and dissolved organic carbon $(6.1$ $\mathrm{mg} / \mathrm{L}$ and $3.3 \mathrm{mg} / \mathrm{L}$ ) concentrations, followed in order of decreasing median concentrations, respectively, by Nepaug River and Clear Brook. The higher median nutrient and organic carbon concentrations in Phelps Brook may be caused by decomposition of organic matter from aquatic plants and wildlife populations in ponds and wetlands upstream from the sampling site. Median total nitrite-plus-nitrate nitrogen concentrations, possibly associated with septic-system leachate, were highest in Nepaug River $(0.12 \mathrm{mg} / \mathrm{L})$ and lowest in Clear Brook (estimated value of $0.04 \mathrm{mg} / \mathrm{L}$ ).

Total nitrogen values in Clear Brook generally were less than the reporting level with only three values detected during routine sampling; therefore, a method described by Mullaney and others (2002) was used to calculate total nitrogen. Total nitrogen was set equal to the detected component of either nitrite-plus-nitrate or Kjeldahl nitrogen. If both components were less than the reporting limit, total nitrogen was set to the higher reporting limit of the two. Using this method, the median total nitrogen in Clear Brook was calculated as $0.11 \mathrm{mg} / \mathrm{L}$. The method was found to have little to no effect on calculated medians for total nitrogen at the other two sites - a 0.02-mg/L difference for Phelps Brook and a 0.0-mg/L difference for the Nepaug River.

Although both suspended and dissolved organic carbon were detected in samples from all three streams, most organic carbon was in the dissolved form. Concentrations of total organic carbon in Nepaug River and Phelps Brook were highly variable during monthly sampling. Concentrations of total organic carbon in Phelps Brook decreased with increasing 
streamflows, indicating dilution of water from the concentrated wetland carbon source, whereas concentrations of total organic carbon in Nepaug River exceeded $13 \mathrm{mg} / \mathrm{L}$ during high flow. Potential sources of organic carbon in the Nepaug River are forested wetlands, runoff from residential land use, and agricultural activities. Phelps Brook had the highest median concentrations of total and dissolved organic carbon, 6.1 and $3.3 \mathrm{mg} / \mathrm{L}$, respectively. In contrast, the median values of total and dissolved organic carbon in monthly samples from Clear Brook were 1.4 and $0.9 \mathrm{mg} / \mathrm{L}$, respectively. The substantial wetland area upstream from the Phelps Brook station contributes significant organic carbon to the brook. Hemond and Benoit (1988) and Waldron and Bent (2001) found that concentrations of dissolved organic carbon were highest in samples from watersheds with the largest percentage of forested wetland area. Besides being a significant source of carbon, wetlands play an important role in transformation of organic carbon. Trihalomethanes were not analyzed in this study, but Waldron and Bent (2001) measured trihalomethane formation potential (THMFP) in basins with wetlands in Massachusetts and found concentrations of THMFP more than three times higher than the USEPA drinking-water standard of $80 \mu \mathrm{g} / \mathrm{L}$.

\section{Fecal Indicator Bacteria}

Samples for analysis of fecal indicator bacteria, including fecal coliform and enterococci, were collected during the monthly water sampling from October 1998 through September 2001. More than 80 percent of the routine samples from the three sites contained bacteria. The highest levels of fecal coliform and enterococci bacteria were in Nepaug River at 1,100 and 868 colonies per 100 milliliters (col/100 mL), respectively, on June 18, 2001 during a storm (table 5). Median concentrations of fecal coliform bacteria during the study period were $23 \mathrm{col} / 100 \mathrm{~mL}$ in Nepaug River, $21 \mathrm{col} / 100 \mathrm{~mL}$ in Phelps Brook, and $7.5 \mathrm{col} / 100 \mathrm{~mL}$ in Clear Brook. The median concentrations of enterococci bacteria during the study period were $31.5 \mathrm{col} / 100 \mathrm{~mL}$ in Nepaug River, $10.5 \mathrm{col} / 100 \mathrm{~mL}$ in Phelps Brook, and $11 \mathrm{col} / 100 \mathrm{~mL}$ in Clear Brook (table 5).

Table 5. Statistical summary of fecal coliform and enterococci bacteria data for U.S. Geological Survey stations in the Nepaug Reservoir watershed, water years 1999-2001.

[Values are given in colonies per 100 milliliters. Contact-recreation standards for fecal coliform bacteria are 400 colonies per 100 milliliters in any individual sample and a geometric mean of 200 colonies per 100 milliliters; contact-recreation standards for enterococci bacteria are 61 colonies per 100 milliliters in any individual sample and a geometric mean of 33 colonies per 100 milliliters (Connecticut Department of Environmental Protection, 1992); k, non-ideal colony count; $<$, less than]

\begin{tabular}{|c|c|c|c|c|c|c|c|c|c|}
\hline \multirow{2}{*}{$\begin{array}{c}\text { U.S. } \\
\text { Geological } \\
\text { Survey station }\end{array}$} & \multirow{2}{*}{$\begin{array}{l}\text { Water } \\
\text { year }\end{array}$} & \multicolumn{4}{|c|}{ Fecal coliform bacteria } & \multicolumn{4}{|c|}{ Enterococci bacteria } \\
\hline & & Minimum & Median & Maximum & $\begin{array}{l}\text { Geometric } \\
\text { mean }\end{array}$ & Minimum & Median & Maximum & $\begin{array}{c}\text { Geometric } \\
\text { mean }\end{array}$ \\
\hline \multirow{3}{*}{$\begin{array}{l}\text { Nepaug River } \\
\text { near Nepaug }\end{array}$} & 1999 & $3 \mathrm{k}$ & 12 & $86 \mathrm{k}$ & 15 & $2 \mathrm{k}$ & 16 & $62 \mathrm{k}$ & 14 \\
\hline & 2000 & $<1 \mathrm{k}$ & 24 & $129 \mathrm{k}$ & 24 & $3 \mathrm{k}$ & 46 & $120 \mathrm{k}$ & 28 \\
\hline & 1999-01 & $<1 \mathrm{k}$ & 23 & $1,100 \mathrm{k}$ & 25 & $2 \mathrm{k}$ & 31.5 & $868 \mathrm{k}$ & 30 \\
\hline \multirow{2}{*}{$\begin{array}{l}\text { Phelps Brook } \\
\text { near } \\
\text { Collinsville }\end{array}$} & 1999 & $<1 \mathrm{k}$ & 35 & $60 \mathrm{k}$ & 21 & $1 \mathrm{k}$ & 15 & 300 & 15 \\
\hline & 2000 & $<1 \mathrm{k}$ & 17 & 96 & 11 & $1 \mathrm{k}$ & 4 & 25 & 4 \\
\hline \multirow{4}{*}{$\begin{array}{l}\text { Clear Brook } \\
\text { near } \\
\text { Collinsville }\end{array}$} & 1999 & 1 & 10 & 30 & 10 & $<1 \mathrm{k}$ & 9 & 45 & 8 \\
\hline & 2000 & $<1 \mathrm{k}$ & 2 & 23 & 3 & $<1 \mathrm{k}$ & 4 & $72 \mathrm{k}$ & 5 \\
\hline & 2001 & $<1 \mathrm{k}$ & 7 & $70 \mathrm{k}$ & 10 & $3 \mathrm{k}$ & 17 & $109 \mathrm{k}$ & 15 \\
\hline & 1999-01 & $<1 \mathrm{k}$ & 7.5 & $70 \mathrm{k}$ & 7 & $<1 \mathrm{k}$ & 11 & $109 \mathrm{k}$ & 8 \\
\hline
\end{tabular}


The Connecticut DEP uses total coliform as the indicator bacteria for evaluating Class AA water (water suitable for existing or proposed drinking-water use); therefore, a direct comparison to the fecal coliform and enterococci data collected in this study was not possible. However, it was possible to compare the geometric mean concentrations that the state uses for waterquality standards for Class B water (water suitable for contact recreation) with the data collected for this study. The geometric mean concentrations for all fecal bacteria samples calculated for the study period at the three stations were less than 50 $\mathrm{col} / 100 \mathrm{~mL}$, well below the state standard of $200 \mathrm{col} / 100 \mathrm{~mL}$ (Connecticut Department of Environmental Protection, 1996, p. 32). The geometric mean concentration for enterococci bacteria was $71 \mathrm{col} / 100 \mathrm{~mL}$ in Nepaug River for the 2001 water year, which exceeds the state standard of $33 \mathrm{col} / 100 \mathrm{~mL}$ (Connecticut Department of Environmental Protection, 1996, p. 32). Samples from the three stations, collectively, exceeded the individual sample concentration standard for enterococci of $61 \mathrm{col} / 100 \mathrm{~mL}$ on 16 occasions during the study period with most occasions (9) reported for Nepaug River.

Boxplots of the number of colonies of bacteria plotted on a log scale indicate that Nepaug River and Phelps Brook have similar populations of fecal coliform bacteria (fig. 6) with no statistical difference between the medians, as calculated using the Wilcoxon rank-sum test ( $\mathrm{p}$-value $=0.42$ ). In Clear Brook, median concentrations of fecal coliform bacteria were significantly lower than in both Nepaug River and Phelps Brook (pvalues $=0.02$ and 0.001 , respectively) and displayed few outliers (fig. 6A). The boxplots for the enterococci bacteria data show that populations in the Nepaug River are significantly larger than populations in Phelps or Clear Brooks (fig. 6B). The greater variability and higher colony counts in Nepaug River may be attributed to several factors, including the larger populations of warm-blooded animals and humans, larger size of the contributing watershed, more residential land use, more numerous septic systems, and more agricultural lands in Nepaug River watershed than in either Phelps or Clear Brook watersheds.
Although no strong linear correlations were seen between bacteria counts and streamflow, seasonal differences between summer (May to October) and winter (November to April) bacteria counts can be seen in samples from the three stations. The summer median values are larger than the winter median values for both fecal coliform and enterococci bacteria at all stations (figs. 7A-C and 8A-C).

\section{Surface-Water Quality During Storms in the Nepaug Reservoir Watershed}

Stormwater samples were collected by three different methods: automated methods (discrete samples), manual methods (grab samples), and automated composite methods (composite samples). The samples indicate variability between stations, constituents, seasons, and storm intensities. Mechanisms for the changing constituent concentrations, as they related to streamflow, turbidity, and specific conductance, also were studied. Individual water samples were collected during 10 separate storms (table 6) during the study period. Samples were collected from at least 1 station, and many times at 2 stations, during a single storm event, resulting in a total of 57 storm samples of various types. Results from the stormwater sampling and selected data from the continuous water-quality monitors are discussed by sampling method and by constituent in this section of the report.

Continuous water-quality-monitoring data were collected for specific conductance, turbidity, dissolved oxygen, $\mathrm{pH}$, and water temperature. Statistical summaries of the 15-minute continuous water-quality-monitoring data-maximum, minimum, and mean - are available upon request from the USGS Connecticut Water Science Center. 
A. Fecal coliform bacteria

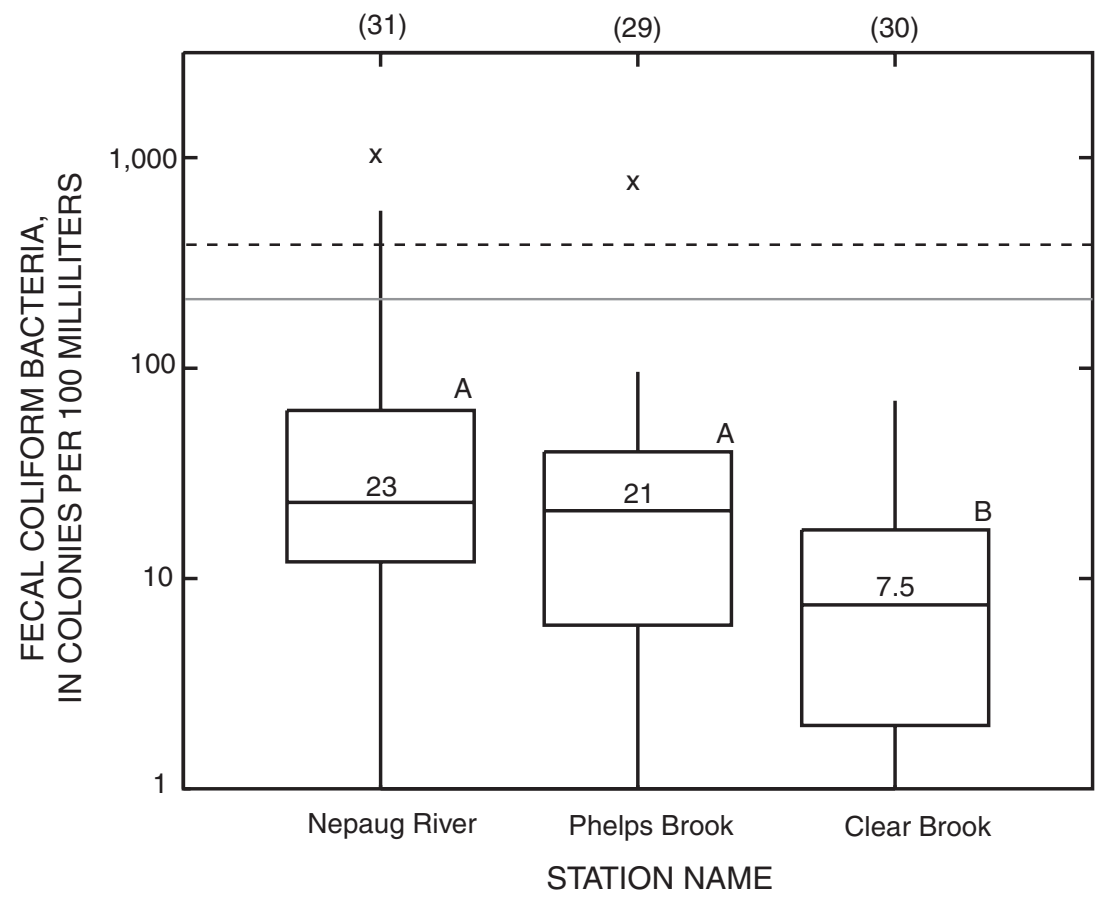

B. Enterococci bacteria

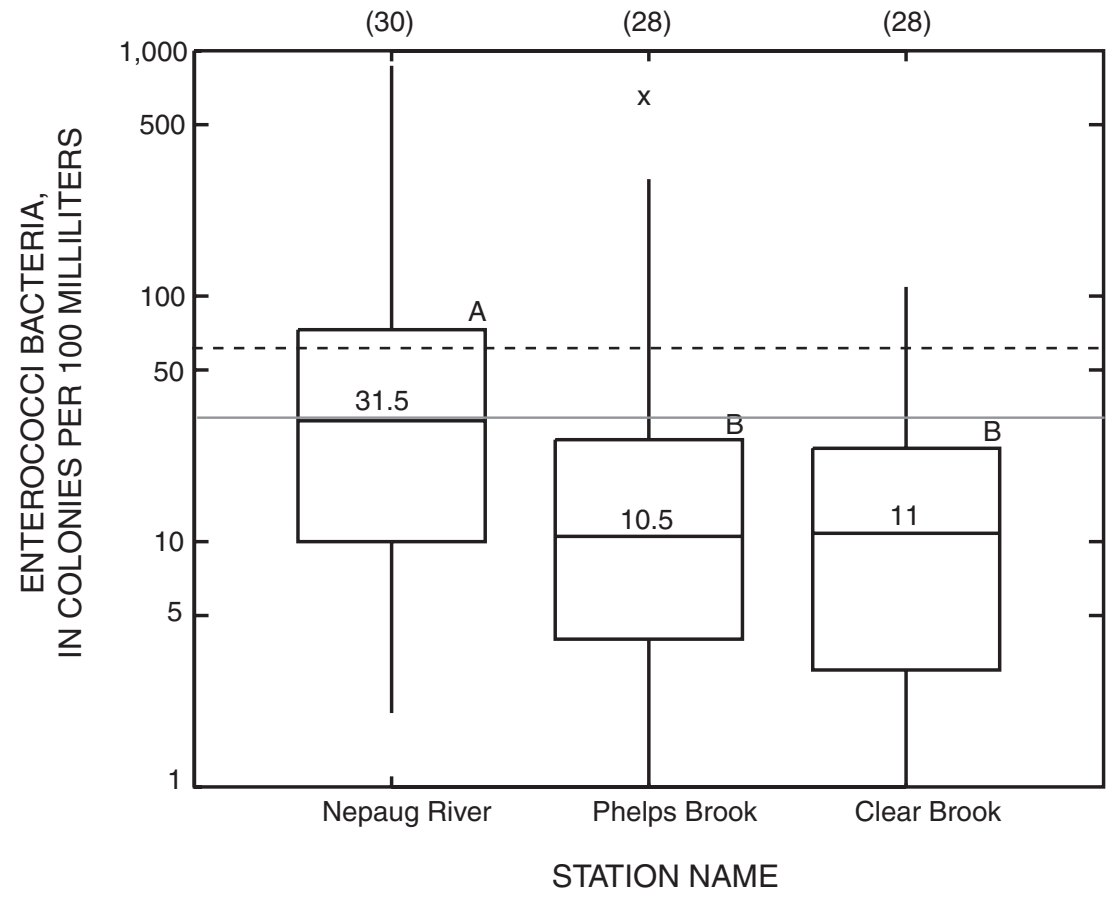

EXPLANATION

(30) Number of values

- Upper detached

x Upper outside

| 75 th percentile

75th percentile
Median

$\lceil$ 25th percentile

Lower adjacent

$x \quad$ Lower outside

- Lower detached

- - - State water-quality standard for an instantaneous sample

_ State water-quality standard for the geometric mean

Sample populations are designated by letters. Populations that share the same letter are not significantly different at the 0.05 level.

Figure 6. The distribution of the concentrations of $A$, fecal coliform bacteria and $B$, enterococci bacteria, Nepaug Reservoir watershed, Connecticut. 


\section{A. Nepaug River}

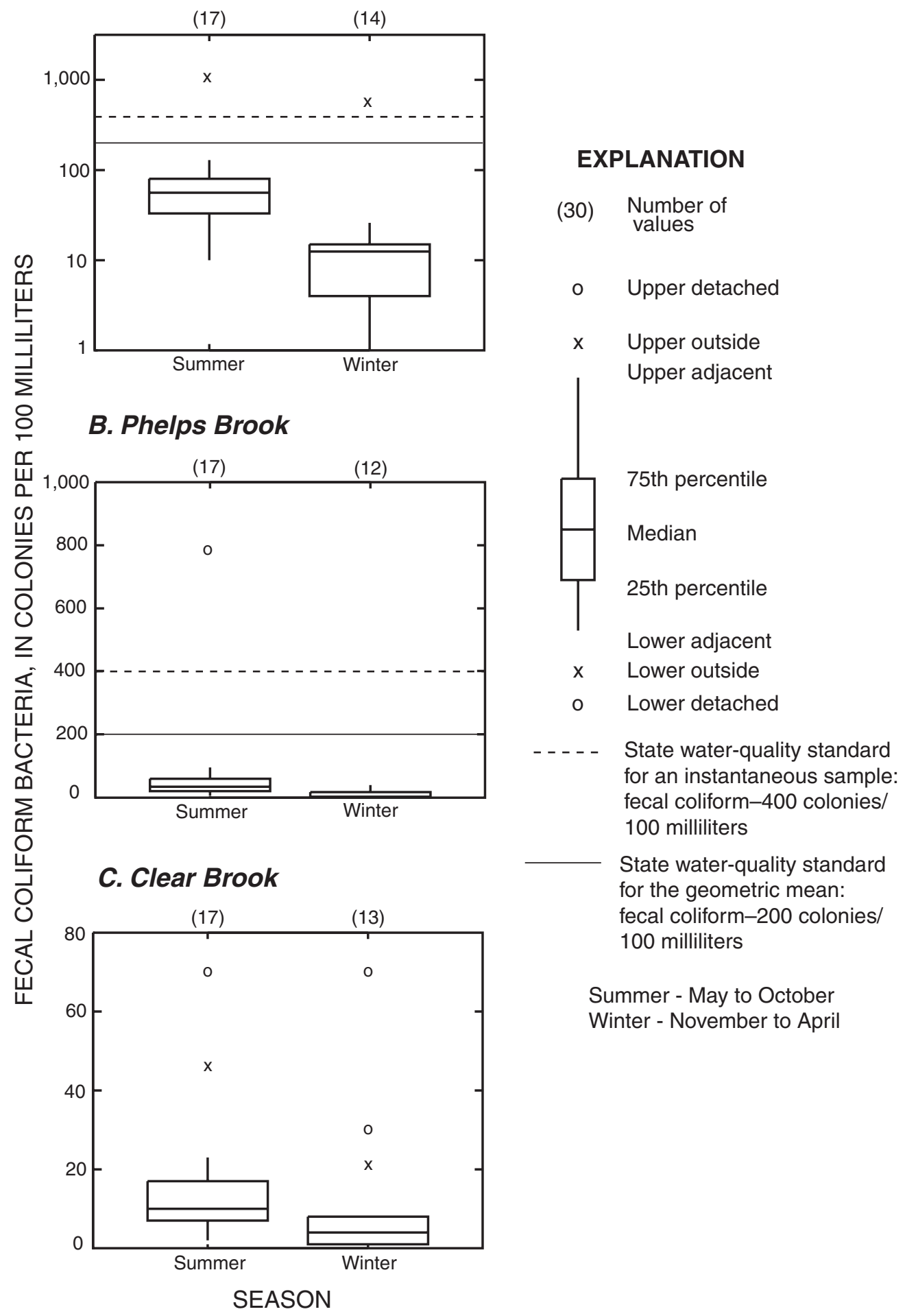

Figure 7. The distribution of the concentrations of fecal coliform bacteria by season at three U.S. Geological Survey stations, 1999-2001: $A$, station 01187800 Nepaug River near Nepaug, Connecticut; $B$, station 01187830 Phelps Brook near Collinsville, Connecticut; and C, station 01187850 Clear Brook near Collinsville, Connecticut. 


\title{
A. Nepaug River
}

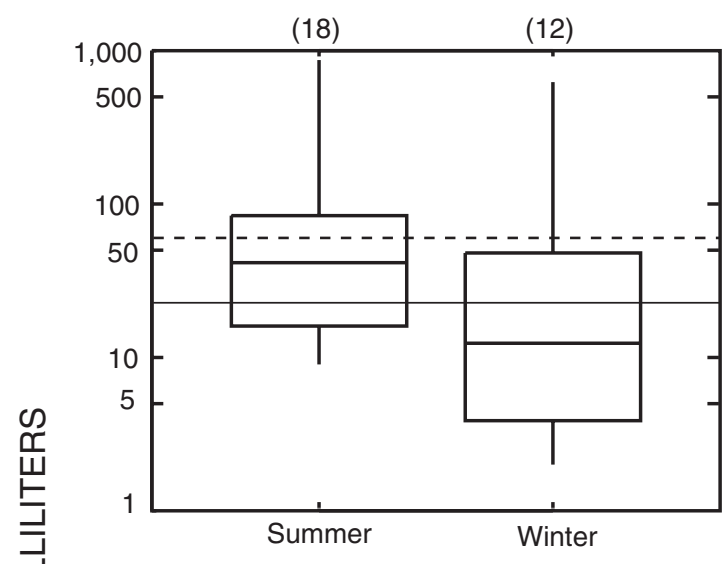

\section{EXPLANATION}

\author{
(30) Number of \\ values \\ - Upper detached \\ X Upper outside \\ Upper adjacent
}

B. Phelps Brook
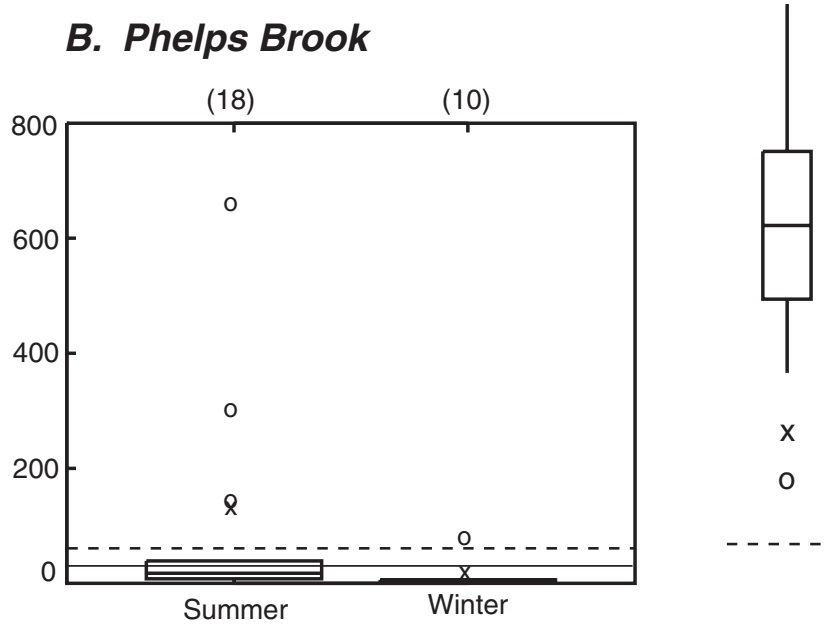

75th percentile

Median

25th percentile

Lower adjacent

$x \quad$ Lower outside

- Lower detached

- - - - State water-quality standard for an instantaneous sample: enterococci-61 colonies/ 100 milliliters

\section{Clear Brook}

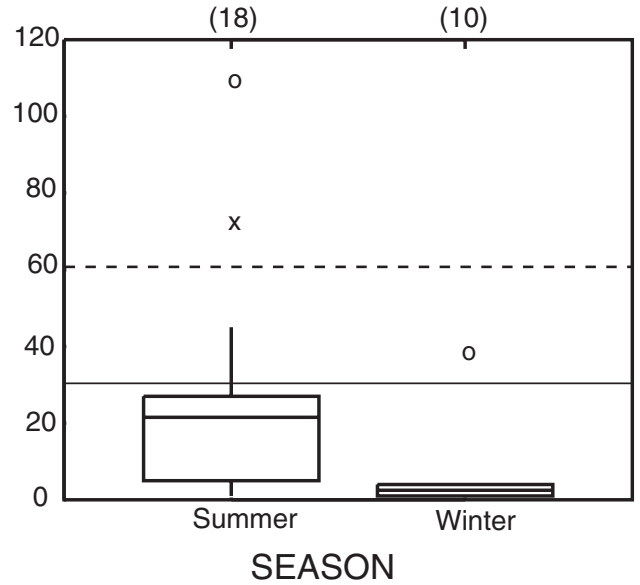

State water-quality standard for the geometric mean: enterococci-33 colonies/ 100 milliliters

Summer - May to October Winter - November to April

Figure 8. The distribution of the concentrations of enterococci bacteria by season at three U.S. Geological Survey stations, 1999-2001: $A$, station 01187800 Nepaug River near Nepaug, Connecticut; $B$, station 01187830 Phelps Brook near Collinsville, Connecticut; and $C$, station 01187850 Clear Brook near Collinsville, Connecticut. 
Table 6. Sampled storms in the Nepaug Reservoir watershed during the study period.

[Discrete samples refer to samples collected both manually (grab) and with the autosampler; all composite samples were collected with the autosampler]

\begin{tabular}{|c|c|c|c|}
\hline Date & Type of sample & $\begin{array}{l}\text { Precipitation } \\
\text { (inches) }\end{array}$ & $\begin{array}{l}\text { Range of streamflow } \\
\text { (cubic feet per second) }\end{array}$ \\
\hline \multicolumn{4}{|c|}{ Station 01187800 Nepaug River near Nepaug, Connecticut } \\
\hline May 19-20, 1999 & Discrete & 1.65 & $13-371$ \\
\hline Sept.10-11, 1999 & Composite/discrete & 2.3 & $3.4-156$ \\
\hline Oct. $19-21,1999$ & Discrete & .36 & $25-62$ \\
\hline Nov. 2-4, 1999 & Composite & 1.65 & $21-270$ \\
\hline Dec. 14-16, 1999 & Composite/discrete & .67 & $32-102$ \\
\hline March 11-14, 2000 & Composite/discrete & 1.8 & $49-376$ \\
\hline March 28-29, 2000 & Composite/discrete & .87 & $42-282$ \\
\hline \multicolumn{4}{|c|}{ Station 01187830 Phelps Brook at Mill Dam Rd. near Collinsville, Connecticut } \\
\hline Sept. 10, 1999 & Discrete & 2.3 & $0.3-12$ \\
\hline Dec. 15,1999 & Discrete & .67 & $4.5-10$ \\
\hline March 11-14, 2000 & Composite/discrete & 1.8 & $5.7-37$ \\
\hline March 28-29, 2000 & Composite/discrete & .87 & $5.2-25$ \\
\hline Nov. $10-11,2000$ & Composite/discrete & 1.19 & $1.8-20$ \\
\hline \multicolumn{4}{|c|}{ Station 01187850 Clear Brook near Collinsville, Connecticut } \\
\hline May 19-20, 1999 & Composite/discrete & 1.65 & $2.0-5.3$ \\
\hline Aug. 14, 1999 & Composite & 1.53 & $1.1-8.1$ \\
\hline Aug. 21, 1999 & Composite & .5 & $1.1-3.9$ \\
\hline Sept. 10, 1999 & Discrete & 2.3 & $.98-18$ \\
\hline Oct. 19-20, 1999 & Composite & .13 & $1.2-1.9$ \\
\hline Nov. 2-3, 1999 & Composite & 1.65 & $1.3-8.5$ \\
\hline Dec. 14-15, 1999 & Composite & .67 & $1.5-2.7$ \\
\hline Nov. $10-11,2000$ & Composite/discrete & 1.19 & $1.2-5.1$ \\
\hline
\end{tabular}

\section{Stom Samples Collected by Automated and Manual Methods}

A statistical summary of the water-quality data (physical properties and nutrient concentrations) from storm samples is presented in table 7 . The following discussion is based on analysis of discrete (including grab samples) water-quality samples.

\section{Physical and Chemically Related Properties}

In pristine watersheds, specific conductance and the concentration of dissolved constituents in stream water are inversely related to streamflow (as streamflow increases, specific conductance and dissolved ion concentrations decrease) because the low ionic strength (low specific conductance) of the precipitation, which increases the streamflow, dilutes the ion concentration of the stream. Because specific conductance and dissolved ion concentration react in the same way, the physical property - specific conductance — can be used as a surrogate for the concentrations of dissolved ions or total dissolved solids. Water-quality data indicate that storms tended to cause dilution of concentrations of dissolved constituents in all three watersheds (figs. 9 and 10). 
Table 7. Statistical summary of water-quality data for selected storms during the study period for U.S. Geological Survey stations in the Nepaug Reservoir watershed.

[Data are for storms listed in table 6. $\mathrm{ft}^{3} / \mathrm{s}$, cubic foot per second; NTU, nephelometric turbidity units; $\mathrm{mg} / \mathrm{L}$, milligrams per liter; N, nitrogen; P, phosphorus; C, carbon; <, less than; E, estimated; --, not applicable (no median values for organic carbon because too few samples were collected)]

\begin{tabular}{|c|c|c|c|c|c|c|c|c|c|}
\hline \multirow[t]{2}{*}{ Water-quality property or constituent (units) } & \multicolumn{3}{|c|}{$\begin{array}{c}\text { Nepaug River near Nepaug } \\
01187800\end{array}$} & \multicolumn{3}{|c|}{$\begin{array}{c}\text { Phelps Brook at Mill Dam Rd. at } \\
\text { Collinsville } \\
01187830\end{array}$} & \multicolumn{3}{|c|}{$\begin{array}{c}\text { Clear Brook near Collinsville } \\
01187850\end{array}$} \\
\hline & Minimum & Median & Maximum & Minimum & Median & Maximum & Minimum & Median & Maximum \\
\hline \multicolumn{10}{|c|}{ PHYSICAL AND CHEMICALLY RELATED PROPERTIES } \\
\hline Discharge, instantaneous $\left(\mathrm{ft}^{3} / \mathrm{s}\right)$ & 2.4 & 35 & 671 & 0.02 & 4.6 & 56 & 0.98 & 1.6 & 6.9 \\
\hline Turbidity (NTU) (from discrete samples) & .50 & 1.0 & 15 & .78 & 1.3 & 13 & .21 & .50 & 12 \\
\hline \multicolumn{10}{|c|}{ CONCENTRATIONS OF NITROGEN, PHOSPHORUS, AND CARBON } \\
\hline Nitrogen, ammonia + organic, dissolved $(\mathrm{mg} / \mathrm{L}$ as $\mathrm{N})$ & 0.12 & 0.20 & 0.45 & 0.18 & 0.20 & 0.41 & E 0.06 & 0.16 & 0.39 \\
\hline Nitrogen, ammonia + organic, total $(\mathrm{mg} / \mathrm{L}$ as $\mathrm{N})$ & .20 & .42 & 1.1 & .25 & .32 & .73 & .12 & .41 & 1.4 \\
\hline Nitrite + nitrate, dissolved $(\mathrm{mg} / \mathrm{L}$ as $\mathrm{N})$ & $<.05$ & .12 & .17 & .05 & .13 & .58 & $<.05$ & .05 & .17 \\
\hline Nitrogen, total $(\mathrm{mg} / \mathrm{L}$ as $\mathrm{N})$ & .30 & .52 & 1.20 & .33 & .51 & 1.30 & .12 & .45 & 1.50 \\
\hline Phosphorus, dissolved (mg/L as $\mathrm{P}$ ) & E.004 & .010 & .026 & E.003 & E.005 & .014 & $<.004$ & .009 & .019 \\
\hline Phosphorus, total (mg/L as $\mathrm{P}$ ) & .012 & .062 & .166 & .010 & .026 & .070 & E.007 & .063 & .290 \\
\hline Organic carbon, particulate (mg/L as $\mathrm{C}$ ) & 1.5 & -- & $<3.4$ & .9 & -- & 1.9 & $<.2$ & -- & $<2.7$ \\
\hline Organic carbon, dissolved (mg/L as C) & 3.7 & -- & 9.8 & 7.9 & -- & 8.1 & 1.1 & -- & 15 \\
\hline Organic carbon, total (mg/L as $\mathrm{C})$ & 9.4 & -- & 13 & 5.3 & -- & 9.7 & 1.2 & -- & 18 \\
\hline
\end{tabular}




\section{Surface-Water Quality and Nutrient Loads in the Nepaug Reservoir Watershed, 1999-2001}

Storm runoff also affected turbidity, which can be measured in place on a continuous basis and used as a surrogate for suspended-sediment concentration, in all three watersheds. Values of turbidity and the relation of turbidity to changes in streamflow differed by storm intensity and among the three sites. Turbidity and concentrations of suspended constituents are directly related to stream discharge - turbidity generally increases as streamflow increases. Although changes in turbidity during storms were highly variable, the same pattern was seen in each watershed: pre-runoff values of turbidity near zero increased during the first flush of a storm as surface runoff collected particulate matter and washed it into the stream; values decreased rapidly after the peak in streamflow. Data for Phelps Brook watershed showed the least pronounced relation between streamflow and turbidity (fig. 9B) probably because of mixing and settling in the wetlands and impoundments above the Phelps Brook sampling station. Turbidity values in Phelps Brook also may have been affected by stream color. Data for Nepaug River watershed showed a distinct correlation between streamflow and turbidity (figs. 9A, 10B), and Clear Brook watershed showed the most response in turbidity to changes in streamflow (fig. 10A). The range of turbidity values, as well as the rate of change in values, differed among sites; different storms during different seasons brought about different responses between streamflow and turbidity. Several major factors affect this relation, including number of days without rainfall before the storm, rainfall intensity during the storm, total rainfall accumulation, and time of year.

\section{Phosphorus, Nitrogen, and Organic Carbon}

Storm samples had the highest concentrations of nutrients measured during the study. The variability in nutrient concentrations during storms is shown by the data for the discrete water samples collected during each storm. These samples represent the nutrient concentration response to physical watershed features, as well as to seasonal and storm-specific factors. Most of the phosphorus detected in the samples was in the form of total phosphorus. Concentrations of dissolved phosphorus never exceeded $0.026 \mathrm{mg} / \mathrm{L}$, even during storms, and orthophosphorus was never quantified above the detection limit. This indicates that the primary mechanism of transport of phosphorus in the three watersheds is as particulate phosphorus associated with sediment and not as dissolved phosphorus.

Concentrations of total phosphorus higher than 0.050 $\mathrm{mg} / \mathrm{L}$ were measured 13 times in Clear Brook during 7 storm events. The maximum concentration of total phosphorus $(0.290$ $\mathrm{mg} / \mathrm{L}$ ) was from a sample collected at the hydrologic peak of the storm on November 10, 2000 (storm total of 1.19 in. of precipitation). There had been no precipitation for 21 days prior to the event. This high nutrient value may indicate nutrient buildup in the watershed during a dry period, followed by a runoff event that washed the nutrients into the stream. The next three highest concentrations of total phosphorus were measured in spring
1999 (0.165 mg/L), summer 1999 (0.196 mg/L), and fall 1999 $(0.123 \mathrm{mg} / \mathrm{L})$. The median concentration of total phosphorus during the sampled storms in Clear Brook was $0.063 \mathrm{mg} / \mathrm{L}$, which is significantly higher than the median concentration of total phosphorus for the routine samples- $0.007 \mathrm{mg} / \mathrm{L}$.

Some factors that cause Clear Brook to have some of the highest nutrient concentrations during storms include steepness of the terrain, proximity of Clear Brook Road, naturally elevated concentrations of nutrients of the forest floor, and mining activity, including the removal of trees and temporary stockpiling of topsoil. Removal of sand and gravel from areas of the watershed, and the consequent removal of vegetation and top soil and steepening of slopes, could cause more frequent and larger amounts of surface-water runoff with greater erosion during storms. Greater runoff and erosion often result in higher suspended-sediment concentrations with associated nutrients.

In the Nepaug River and Phelps Brook watersheds, concentrations of total phosphorus during storms were lower than concentrations in Clear Brook. The maximum concentration of phosphorus at the Nepaug River station was $0.166 \mathrm{mg} / \mathrm{L}$ during the fall 1999 storm. In samples from the Nepaug River watershed, the median concentration of total phosphorus during sampled storms was $0.062 \mathrm{mg} / \mathrm{L}$, compared to a median concentration of $0.013 \mathrm{mg} / \mathrm{L}$ for routine samples; 10 of the 19 storm samples had phosphorus concentrations higher than 0.050 $\mathrm{mg} / \mathrm{L}$. In Phelps Brook, two samples had a concentration of total phosphorus higher than $0.050 \mathrm{mg} / \mathrm{L}$-fall $1999(0.070 \mathrm{mg} / \mathrm{L})$ and fall $2000(0.068 \mathrm{mg} / \mathrm{L})$.

During storms, total phosphorus concentrations in Clear Brook responded directly to changes in streamflow. In general, the concentrations of total phosphorus were highest during peaks in streamflow (fig.10A). During the May 1999 storm, the concentration of total phosphorus initially increased as the streamflow increased, then dropped when the streamflow dropped. The concentration of total phosphorus then increased rapidly, coinciding with the next increase in streamflow, and decreased after the peak in streamflow.

The concentration of total phosphorus in the Nepaug River followed a similar pattern as Clear Brook. The concentration of total phosphorus was higher prior to and at the peak of streamflow and decreased rapidly after the peak in streamflow. (See data from the May 1999 and the March 2000 storms in fig. 10B and 9A.) This response is fairly common for constituents that are transported as suspended load, such as suspended sediment and constituents such as total phosphorus that are associated with suspended sediment. Although the total phosphorus concentration data varied only slightly during the March 2000 storm in Phelps Brook, the concentration of total phosphorus was the highest prior to the peak in streamflow and lower at the peak in streamflow (fig. 9B). This pattern of highest concentrations prior to and at the peak in streamflow and decreasing rapidly after the peak is know as hysteresis. Hysteresis in constituent data can complicate the process of predicting constituent concentration based on streamflow. 


\section{A. Nepaug River}

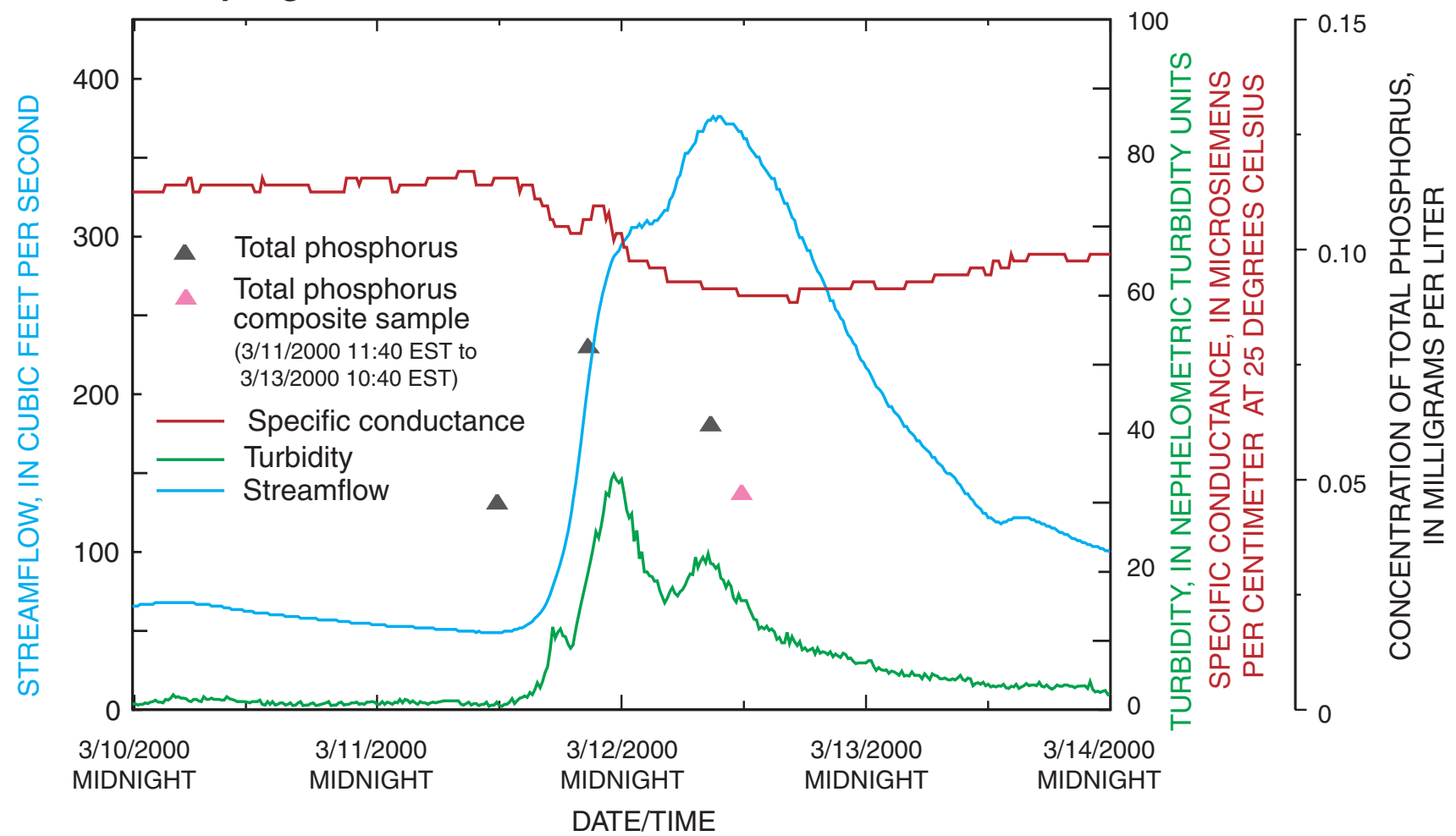

\section{B. Phelps Brook}

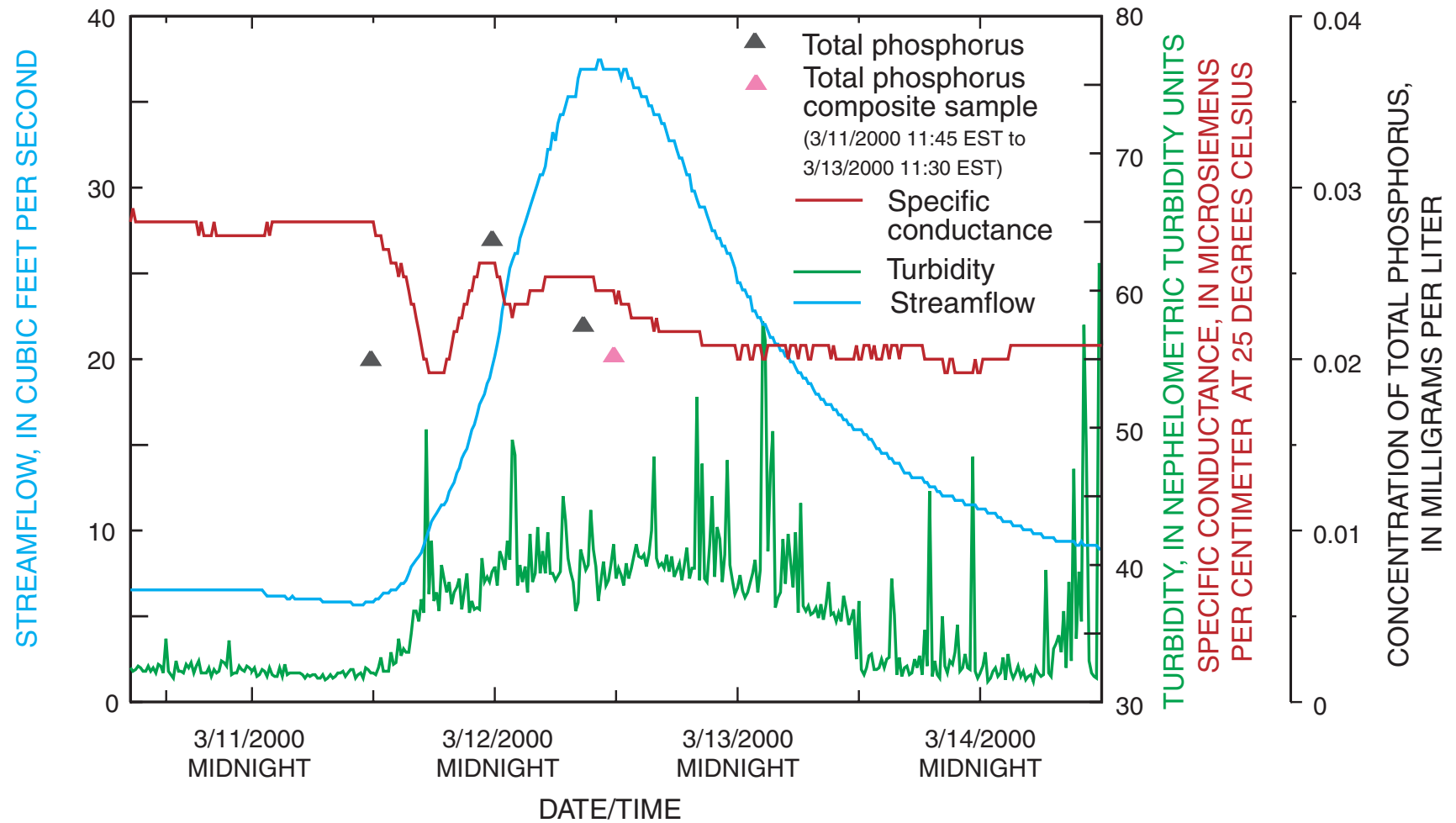

Figure 9. Continuous water-quality-monitoring data and concentration of total phosphorus at two U.S. Geological Survey stations: A, station 01187800 Nepaug River near Nepaug, Connecticut; and B, station 01187830 Phelps Brook near Collinsville, Connecticut, March 10-14, 2000. 

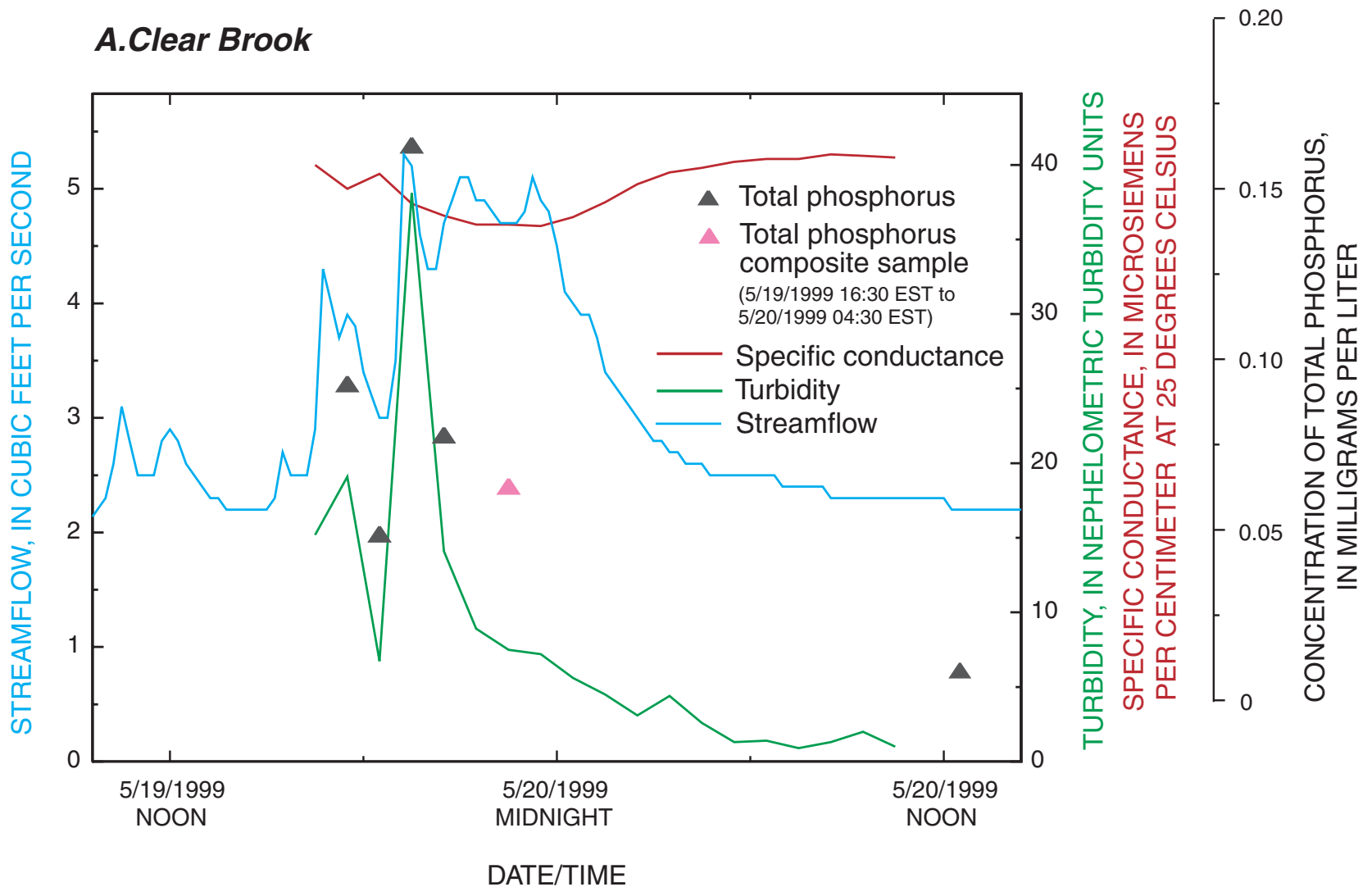

\section{B. Nepaug River}

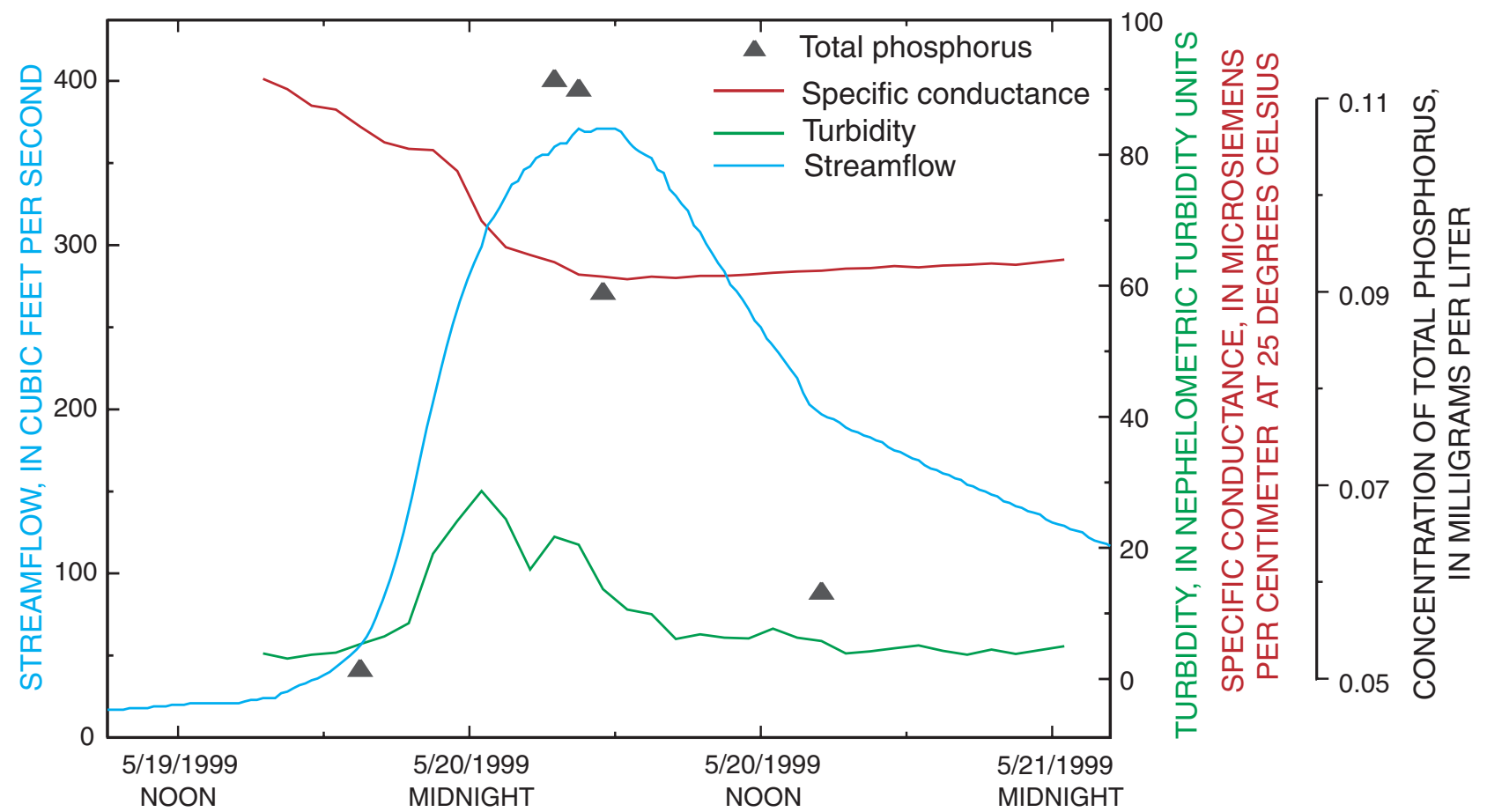

DATE/TIME

Figure 10. Continuous water-quality-monitoring data and concentration of total phosphorus at $A$, station 01187850 Clear Brook near Collinsville, Connecticut; and B, station 01187800 Nepaug River near Nepaug, Connecticut, May 19-21, 1999. 
In general, concentrations of total nitrogen showed little variation among the sites, except during storms, but stations were sampled less frequently for total nitrogen than for total phosphorus. Median concentrations of total nitrogen in samples collected during storms were similar to median concentrations in routine samples, and ranged from $0.45 \mathrm{mg} / \mathrm{L}$ at Clear Brook to $0.52 \mathrm{mg} / \mathrm{L}$ at Nepaug River (table 7). The biggest difference between the storm data and the routine sampling data was in the maximum concentrations: at Clear Brook, the maximum concentration of total nitrogen during a storm was $1.50 \mathrm{mg} / \mathrm{L}$, which is significantly higher than the maximum concentration of total nitrogen during routine sampling of $0.94 \mathrm{mg} / \mathrm{L}$ (table 4). As with total phosphorus, the maximum concentration of total nitrogen during a storm was in a sample from Clear Brook, which had the lowest median concentration of total nitrogen in both the routine and storm samples (see tables 4 and 7).

Changes in total nitrogen concentrations during storms are usually the result of an increase in the particulate phase of nitrogen (total ammonia and organic nitrogen). This can be seen in the storm data for all three watersheds (table 7). Similar results were reported from Sasco Brook in southwestern Connecticut (Morrison, 2002) and Broad Brook in north-central Connecticut (Mullaney and Zimmerman, 1997). Water-quality data from those studies showed that during a storm, concentrations of the dissolved species of nitrogen decreased, whereas the particulate species of nitrogen increased. Even though the species of nitrogen changed considerably, the concentrations of total nitrogen did not.

Storm samples for organic carbon were limited in number because of more restrictive sampling protocols; 19 grab samples were collected for analysis of organic carbon during storms (table 7). Samples were analyzed for both particulate and dissolved forms of organic carbon, and most organic carbon was found to be in the dissolved form. This is unlike the relation for total phosphorus and total nitrogen, when most of the constituent was found in the total or suspended form. Concentrations of total organic carbon during storms were often higher than in the routine monthly samples. The Phelps Brook watershed had the most consistently large values; however, as with total phosphorus and total nitrogen, Clear Brook had the maximum concentration of total organic carbon during a storm $(18 \mathrm{mg} / \mathrm{L})$.

\section{Storm Samples Collected by Automated Composite Methods}

One of the objectives of storm sampling is to characterize the average concentration of nutrients during storms so that daily constituent loads (discussed in a later section of this report) can be calculated. Composite samples provide an average, flow-weighted concentration for a storm; however, these samples do not offer any insight into maximum concentrations of constituents or the timing of those maximum concentrations. Because of the low concentrations of total phosphorus prior to and after the peak in streamflow, the concentration of phosphorus in the flow-weighted composite samples is generally low compared to the samples from near the peak in streamflow. A comparison of concentrations measured in discrete and composite samples is shown in figures 9A, 9B, and 10A. Flowweighted composite samples may be useful in characterizing concentrations of water-quality constituents; however, care must be taken in interpreting what they represent, particularly for constituents associated with suspended sediment, such as phosphorus. Both discrete and composite samples can be collected to characterize constituent transport and the appropriate sampling scheme to use for the desired objective.

Low variability in nutrient concentrations during stormflow means that the flow-weighted composite samples will accurately represent overall storm concentrations. Concentrations of total phosphorus, specific conductance, and turbidity in Phelps Brook showed low variability during the sampled storms. The relatively minor chemical or physical changes may be a result of storage, flushing time, or the amount of mixing that takes place in the large wetlands upstream from the Phelps Brook sampling site. It also may be a result of low suspendedsediment transport from this watershed. As shown in figure 9B, the composite samples for total phosphorus were representative of the entire storm. By contrast, samples from Nepaug River and Clear Brook showed greater variability and elevated concentrations of total phosphorus prior to peak streamflow. Therefore, the composite samples from Nepaug River and Clear Brook for total phosphorus may underrepresent the overall storm concentration (figs. 9A and 10A).

\section{Data from Continuous Monitors}

Water-quality data from continuous monitors can be combined with the results from discrete samples to evaluate the changes in water quality associated with changes in streamflow during storms. Continuous-monitor data show the abrupt changes in physical and chemical water-quality constituents that take place throughout the storm. In Clear Brook, Nepaug River, and Phelps Brook, continuous-monitor data show that specific conductance decreased after the onset of the storm, signifying dilution and lower specific conductance from precipitation runoff (figs. 9 and 10).

Concentrations of total phosphorus from discrete samples were compared to measurements of physical properties, including streamflow, specific conductance, and turbidity, from continuous monitors. Concentrations of total phosphorus are positively and strongly correlated to turbidity in Phelps Brook, Clear Brook, and the Nepaug River, although the concentrations are less strongly correlated at Phelps Brook because fewer storm samples were collected at this location (figs. 9 and 10). Correlation coefficients are 0.83 at Phelps Brook, 0.91 at Clear Brook, and 0.95 at the Nepaug River. A linear regression model of total phosphorus to turbidity in Clear Brook and Nepaug River produces strong relations with coefficient of determination $\left(\mathrm{r}^{2}\right)$ values of 0.83 and 0.91 , respectively (fig. 11). This indicates that 83 percent (Clear Brook) and 91 percent (Nepaug River) of the variability in concentrations of total phosphorus can be predicted using turbidity values. This regression model could allow a value for total phosphorus concentrations to be 
estimated for times when turbidity was measured but no concurrent discrete sample was collected. Using turbidity as a surrogate for suspended sediment, these data corroborate that changes in concentrations of total phosphorus, brought on by changes in streamflow, were caused by the association of total phosphorus with the transport of suspended sediment.

During Tropical Storm Floyd in September 1999, no discrete water-quality samples were collected at any of the stations, but the continuous water-quality monitor in Clear Brook was operating. This storm was the largest and most intense storm during the study period, with more than 9 in. of rain falling locally in less than 48 hours. The sharp crest of the streamflow hydrograph, which is measured in hours rather than days, shows the rapid response of this small watershed from the onset of the storm to the peak in streamflow (lag-to-peak). The data recorded show that the effects of runoff in the watershed caused significant changes in the water quality of Clear Brook (fig. 12). The following conditions were observed: (1) water temperature increased with surface runoff, (2) $\mathrm{pH}$ decreased $1.5 \mathrm{pH}$ units and specific conductance decreased $25 \mu \mathrm{S} / \mathrm{cm}$ because of the low $\mathrm{pH}$ and specific conductance of the precipitation, and (3) turbidity increased three orders of magnitude as more sediment was transported with the increased streamflow.

During this storm, turbidity values increased from less than 1 NTU to more than 300 NTUs, which is an order of magnitude larger than any value for which a concurrent discrete total phosphorus sample was collected. Based on the direct cor- relation between total phosphorus and turbidity, concentrations of total phosphorus during this storm probably were the highest values during the study period. Using the linear regression model of total phosphorus to turbidity (described earlier), it can be estimated that the total phosphorus concentration may have been $0.5 \mathrm{mg} / \mathrm{L}$ when turbidity reached 300 NTUs during Tropical Storm Floyd. Because the values of turbidity and total phosphorus concentrations used to calibrate the regression model were much lower than the values estimated for the storm, the estimated values may have significant error and therefore were not used to estimate phosphorus loads.

\section{Nutrient Loads and Yields to the Nepaug Reservoir}

Annual and monthly loads of total nitrogen, total phosphorus, and total organic carbon were computed for the Nepaug River, Phelps Brook, and Clear Brook watersheds. A regression model was developed for each constituent load that was calculated for each watershed; coefficients for the explanatory variable terms used, term coefficients, and coefficients of determination for the models are shown in table 8. Annual loads and yields of total nitrogen, total phosphorus, and total organic carbon to Nepaug Reservoir are shown in table 9.

Table 8. Explanatory variable terms, term coefficients, and coefficients of determination used in nutrient load estimates for tributaries to the Nepaug Reservoir.

[Ln, natural logarithm; Q, streamflow: T, decimal time in years; $\mathrm{r}^{2}$, coefficient of determination]

\begin{tabular}{|c|c|c|c|c|c|c|c|}
\hline $\begin{array}{c}\text { U.S. } \\
\text { Geological } \\
\text { Survey } \\
\text { station }\end{array}$ & $\begin{array}{c}\text { Regression } \\
\text { intercept }\end{array}$ & $\operatorname{Ln}(0)$ & $\ln \left(0^{2}\right)$ & $\mathbf{T}$ & $\begin{array}{c}\text { sine } \\
\text { (time) }\end{array}$ & $\begin{array}{c}\text { cosine } \\
\text { (time) }\end{array}$ & $\begin{array}{l}\text { Coefficient of } \\
\text { determination } \\
\left(r^{2}\right)\end{array}$ \\
\hline \multicolumn{8}{|c|}{ TOTAL NITROGEN } \\
\hline 01187800 & 4.0502 & 1.2160 & 0.0367 & -- & -0.2113 & -0.1911 & 96.8 \\
\hline 01187830 & 2.4099 & 1.1154 & -- & -- & -.2115 & -.0980 & 96.7 \\
\hline 01187850 & .0864 & 1.559 & .8806 & -- & -.5745 & .0020 & 69.1 \\
\hline \multicolumn{8}{|c|}{ TOTAL PHOSPHORUS } \\
\hline 01187800 & 1.5769 & 1.4386 & 0.1761 & -- & -0.3089 & -0.4703 & 92.3 \\
\hline 01187830 & -2.0116 & .9047 & .0685 & 0.1931 & -- & -- & 93.8 \\
\hline 01187850 & -1.4944 & 3.1291 & -- & -.3464 & -.6426 & .2580 & 73.8 \\
\hline \multicolumn{8}{|c|}{ TOTAL ORGANIC CARBON } \\
\hline 01187800 & 6.0300 & 1.3281 & -- & 0.0796 & -0.4284 & -0.2717 & 97.8 \\
\hline 01187830 & 4.6554 & 1.2788 & -- & -- & -.5818 & -.2815 & 97.2 \\
\hline 01187850 & 1.7135 & .7033 & 1.2366 & .2162 & -.0634 & -.2880 & 74.9 \\
\hline
\end{tabular}




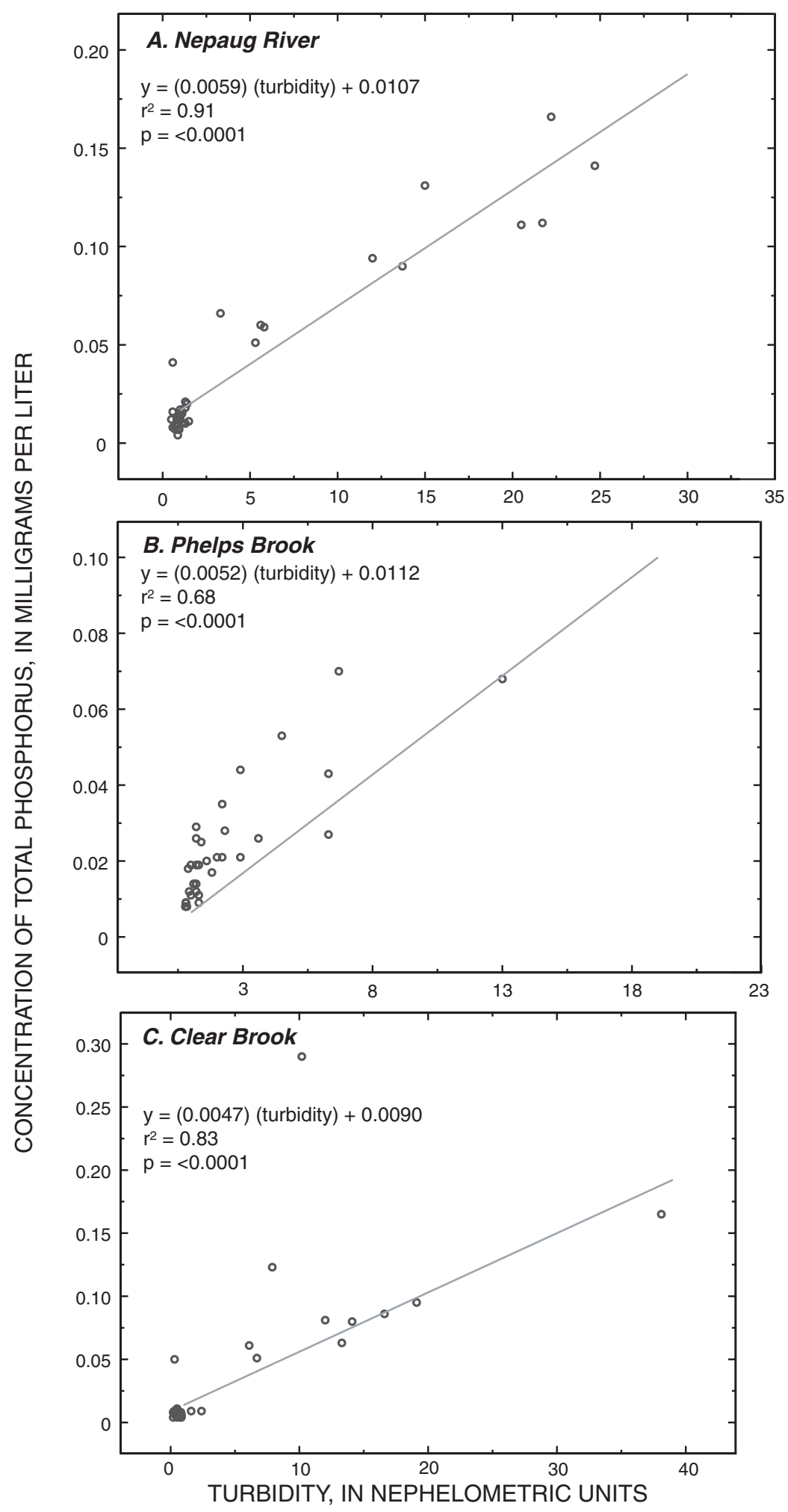

Figure 11. Relation of total phosphorus to turbidity at three U.S. Geological Survey stations: $A$, station 01187800 Nepaug River near Nepaug, Connecticut; $B$, station 01187830 Phelps Brook near Collinsville, Connecticut; and $C$, station 01187850 Clear Brook near Collinsville, Connecticut. $[<$, less than $]$ 


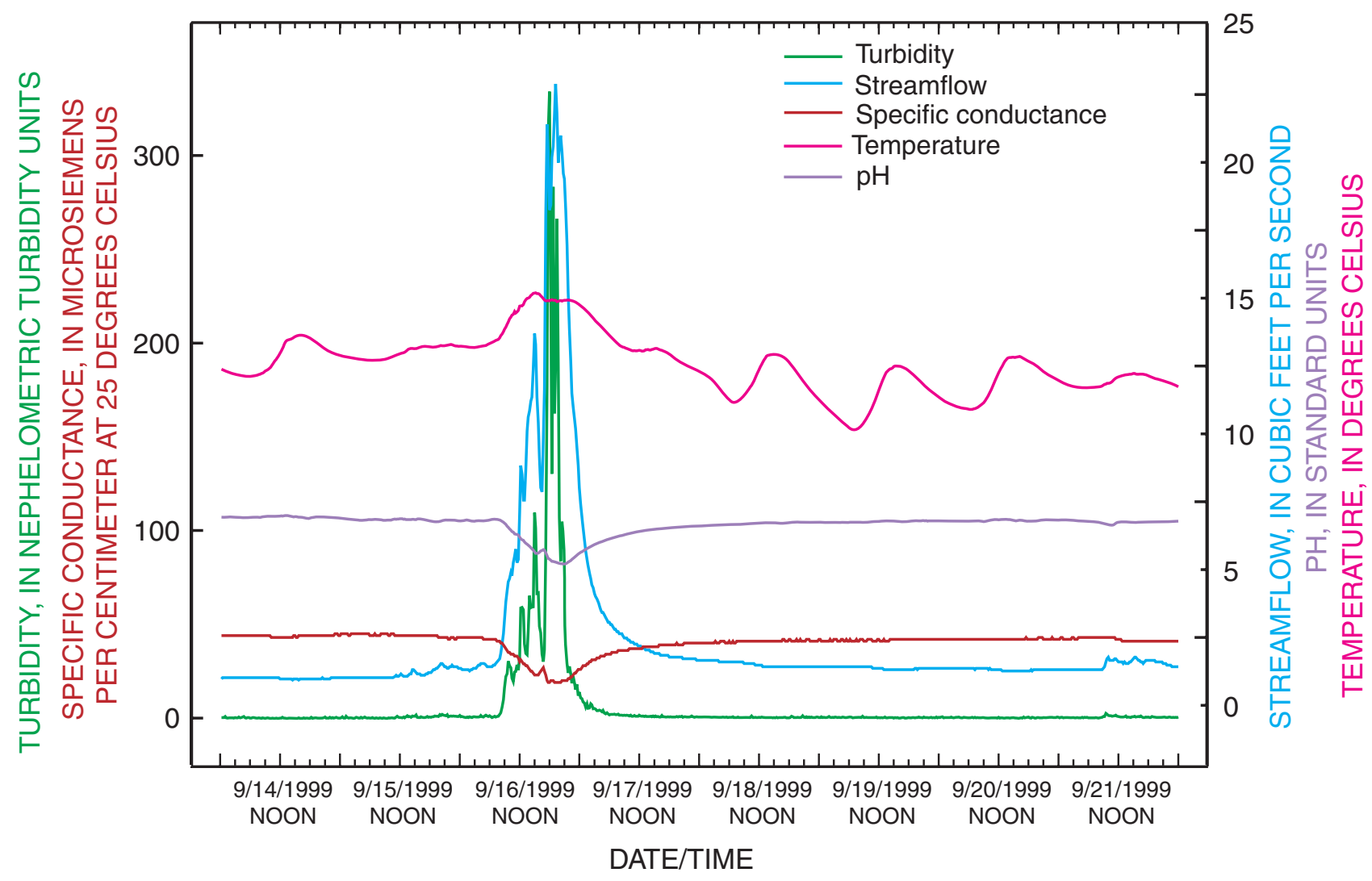

Figure 12. Continuous water-quality-monitoring data, U.S. Geological Survey station 01187850 Clear Brook near Collinsville, Connecticut, September 14-21, 1999. 
Table 9. Annual loads and yields of nutrients and total organic carbon for U.S. Geological Survey stations in the Nepaug Reservoir watershed.

[lb, pound; $\mathrm{mi}^{2}$, square mile; LAD, least absolute deviation; na, not available]

\begin{tabular}{|c|c|c|c|c|c|c|c|c|c|c|c|c|c|c|}
\hline \multirow{3}{*}{$\begin{array}{l}\text { U.S. } \\
\text { Geological } \\
\text { Survey } \\
\text { station }\end{array}$} & \multirow{3}{*}{$\begin{array}{c}\text { Water } \\
\text { year }\end{array}$} & \multicolumn{4}{|c|}{ Total nitrogen } & \multicolumn{4}{|c|}{ Total phosphorus } & \multicolumn{5}{|c|}{ Total organic carbon } \\
\hline & & \multirow{2}{*}{$\begin{array}{c}\text { Load } \\
\text { (lb) }\end{array}$} & \multicolumn{2}{|c|}{$\begin{array}{l}\text { 95-percent } \\
\text { confidence limit for } \\
\text { load (lb) }\end{array}$} & \multirow{2}{*}{$\begin{array}{c}\text { Yield } \\
\left(\mathrm{lb} / \mathrm{mi}^{2}\right)\end{array}$} & \multirow{2}{*}{$\begin{array}{c}\text { Load } \\
\text { (lb) }\end{array}$} & \multicolumn{2}{|c|}{$\begin{array}{l}\text { 95-percent } \\
\text { confidence limit for } \\
\text { load (lb) }\end{array}$} & \multirow{2}{*}{$\begin{array}{c}\text { Yield } \\
\left(\mathrm{lb} / \mathrm{mi}^{2}\right)\end{array}$} & \multirow{2}{*}{$\begin{array}{l}\text { Load } \\
\text { (lb) }\end{array}$} & \multicolumn{2}{|c|}{$\begin{array}{c}\text { 95-percent } \\
\text { confidence limit for } \\
\text { load (lb) }\end{array}$} & \multirow{2}{*}{$\begin{array}{l}\text { Variance } \\
\text { (LAD } \\
\text { method) }\end{array}$} & \multirow{2}{*}{$\begin{array}{c}\text { Yield } \\
\left(\mathrm{lb} / \mathrm{mi}^{2}\right)\end{array}$} \\
\hline & & & Lower & Upper & & & Lower & Upper & & & Lower & Upper & & \\
\hline \multirow{3}{*}{$\begin{array}{l}\text { Nepaug } \\
\text { River near } \\
\text { Nepaug }\end{array}$} & 1999 & 33,800 & 24,900 & 45,000 & 1,440 & 5,370 & 1,240 & 15,400 & 228 & 360,000 & 278,000 & 458,000 & na & 15,300 \\
\hline & 2000 & 39,100 & 32,500 & 46,700 & 1,660 & 3,800 & 2,430 & 5,680 & 162 & 444,000 & 386,000 & 508,000 & na & 18,900 \\
\hline & 2001 & 36,600 & 29,100 & 45,400 & 1,560 & 4,040 & 2,680 & 5,850 & 172 & 400,000 & 339,000 & 468,000 & na & 17,000 \\
\hline \multirow{3}{*}{$\begin{array}{l}\text { Phelps } \\
\text { Brook near } \\
\text { Collins- } \\
\text { ville }\end{array}$} & 1999 & 3,110 & 2,430 & 3,920 & 1,150 & 138 & 16.0 & 391 & 51.1 & 83,200 & $\mathrm{na}^{1}$ & na & 14,300 & 30,800 \\
\hline & 2000 & 4,510 & 3,940 & 5,160 & 1,670 & 182 & 76.9 & 471 & 67.4 & 75,800 & na & na & 2,240 & 28,100 \\
\hline & 2001 & 5,530 & 4,660 & 6,520 & 2,050 & 244 & 106 & 591 & 90.4 & 75,700 & na & na & 2,440 & 28,000 \\
\hline \multirow{3}{*}{$\begin{array}{l}\text { Clear } \\
\text { Brook near } \\
\text { Collins- } \\
\text { ville }\end{array}$} & 1999 & 685 & 552 & 841 & ${ }^{2} 1,090$ & 108 & 27.7 & 291 & ${ }^{2} 171$ & 5,100 & na & na & 9,370 & ${ }^{2} 8,100$ \\
\hline & 2000 & 535 & 490 & 850 & ${ }^{2} 850$ & 61.6 & 39.5 & 91.4 & ${ }^{2} 97.8$ & 4,950 & na & na & 1,290 & ${ }^{2} 7,860$ \\
\hline & 2001 & 467 & 419 & 742 & ${ }^{2} 741$ & 34.6 & 19.3 & 56.9 & ${ }^{2} 54.9$ & 5,460 & na & na & 2,770 & ${ }^{2} 8,670$ \\
\hline
\end{tabular}

${ }^{1}$ Confidence intervals not available; LAD (least absolute deviation) method was used because of outliers.

${ }^{2}$ Yields from Clear Brook indicate a watershed area that is probably smaller than its contributing area. 


\section{Nitrogen Loads and Yields}

Annual loads of total nitrogen from the three tributaries to the Nepaug Reservoir differed substantially in each watershed and among the watersheds during the study period. The largest loads of total nitrogen were from the Nepaug River, whose watershed is much larger than those of Phelps or Clear Brooks. Annual loads of total nitrogen from the Nepaug River watershed were estimated using a regression model that included the natural $\log$ of streamflow, the natural $\log$ of streamflow squared, and the seasonal terms sine and cosine as explanatory variables (table 8). The annual load of total nitrogen from the Nepaug River watershed ranged from 33,800 pounds (lb) during water year 1999 (a relatively dry year) to $39,100 \mathrm{lb}$ during water year 2000 , with an average value of $36,500 \mathrm{lb}$. The seasonal load data indicate that the largest load delivery of total nitrogen from the Nepaug watershed is in the spring when streamflows tend to be highest. In water year 1999, however, runoff from Tropical Storm Floyd (in September) contributed approximately 25 percent of the annual load of total nitrogen at this station. The average annual yield of total nitrogen was 1,550 pounds per square mile per year $\left(\mathrm{lb} / \mathrm{mi}^{2} / \mathrm{yr}\right)$ during water years $1999-2001$, with a range of $1,440 \mathrm{lb} / \mathrm{mi}^{2} / \mathrm{yr}$ (water year 1999 ) to $1,660 \mathrm{lb} / \mathrm{mi}^{2} / \mathrm{yr}$ (water year 2000).

In Phelps Brook, loads of total nitrogen were estimated using a regression model that included the natural log of streamflow and the seasonal terms sine and cosine as explanatory variables. Annual loads of total nitrogen from the Phelps Brook watershed ranged from $3,110 \mathrm{lb}$ (water year 1999) to 5,530 lb (water year 2001), with an average value of 4,380 lb. Runoff from Tropical Storm Floyd contributed more than 20 percent of the annual load of total nitrogen during water year 1999. Nitrogen yields were more variable from the Phelps Brook watershed than from the Nepaug River watershed, possibly because of nutrient storage in the wetlands. The average annual yield of total nitrogen ranged from $1,150 \mathrm{lb} / \mathrm{mi}^{2} / \mathrm{yr}$ (water year 1999) to $2,050 \mathrm{lb} / \mathrm{mi}^{2} / \mathrm{yr}$ (water year 2001 ).

The lowest annual loads of total nitrogen were from the Clear Brook watershed; this result was expected because of the very small size of this watershed $\left(0.63 \mathrm{mi}^{2}\right)$. Annual loads of total nitrogen from the Clear Brook watershed were estimated using a regression model that included the same terms as the Nepaug model. Annual loads of total nitrogen from the Clear Brook watershed ranged from $467 \mathrm{lb}$ (water year 2001) to 685 lb (water year 1999). Unlike the loads from the Nepaug River and Phelps Brook watersheds, the largest load was contributed during the relatively dry water year 1999 . This could be because streamflow at Clear Brook was normal during the dry summer months of 1999 whereas streamflows in the other two watersheds were much lower than normal. It also was a direct effect of Tropical Storm Floyd, which resulted in very large increases in both streamflow and load. Annual total nitrogen loads and yields in Clear Brook were unlike loads and yields from Nepaug River and Phelps Brook, because, with the exception of the effects of Tropical Storm Floyd in September 1999, single events in Clear Brook carried a lower percentage of the yearly total nitrogen load. Runoff from Tropical Storm Floyd contributed an estimated 25 percent of the 1999 water year annual load. Annual loads of total nitrogen were relatively evenly distributed throughout each water year. The even distribution of annual load is consistent with the uniform distribution of streamflow throughout the water year. Annual yields of total nitrogen from the Clear Brook watershed were approximately 50 percent lower than yields in either of the other two watersheds, ranged from $741 \mathrm{lb} / \mathrm{mi}^{2} / \mathrm{yr}$ (water year 2001) to $1,090 \mathrm{lb} / \mathrm{mi}^{2} / \mathrm{yr}$ (water year 1999), and averaged $894 \mathrm{lb} / \mathrm{mi}^{2} / \mathrm{yr}$. Yield estimates for the Clear Brook watershed have a high bias because the topographic drainage area is smaller than the contributing area.

The hysteresis in nutrient data for storms generally has less effect on total nitrogen than on total phosphorus. As a result, calculating (predicting) loads of total nitrogen based on streamflow is slightly more robust than predicting loads of total phosphorus. Concentrations of total nitrogen tend to increase with increases in streamflow; however, the proportions of constituent concentrations of dissolved nitrate and nitrite and total kjeldahl nitrogen (used to calculate total nitrogen) change significantly during a storm. This variability can be seen in the confidence intervals for predicting total nitrogen load, which are narrower than the intervals for total phosphorus (table 9).

\section{Phosphorus Loads and Yields}

Annual loads of total phosphorus from the Nepaug River watershed differed by an order of magnitude from those of Phelps Brook and Clear Brook watersheds. Annual loads of total phosphorus in the Nepaug River watershed were estimated using the same regression model terms as those used for total nitrogen - the explanatory variables included two streamflow terms as well as a seasonal component. Annual loads of total phosphorus from the Nepaug River watershed ranged from $3,800 \mathrm{lb}$ (water year 2000) to $5,370 \mathrm{lb}$ (water year 1999). Increased runoff from Tropical Storm Floyd contributed very large loads of total phosphorus during September 1999. The monthly load during September 1999 was estimated to be 59 percent of that water year's total annual load and 24 percent of the load during the entire study period. Annual yields of total phosphorus ranged from $162 \mathrm{lb} / \mathrm{mi}^{2} / \mathrm{yr}$ (water year 2000) to 228 $\mathrm{lb} / \mathrm{mi}^{2} / \mathrm{yr}$ (water year1999) and averaged $187 \mathrm{lb} / \mathrm{mi}^{2} / \mathrm{yr}$.

For the Phelps Brook watershed, annual loads of total phosphorus were estimated using a regression model with three explanatory variables, including the natural $\log$ of streamflow, the natural $\log$ of streamflow squared, and time. Annual loads for total phosphorus ranged from $138 \mathrm{lb}$ (water year 1999) to $244 \mathrm{lb}$ (water year 2001) and averaged $188 \mathrm{lb}$. Because of Tropical Storm Floyd, monthly loads in September contributed approximately 47 percent of the total phosphorus load that year and 11 percent of the total phosphorus load during the study period. Total phosphorus yields for the Phelps Brook watershed were less than half of the yields of the Nepaug River watershed and ranged from $51.1 \mathrm{lb} / \mathrm{mi}^{2} / \mathrm{yr}$ (water year 1999) to 90.4 $\mathrm{lb} / \mathrm{mi}^{2} / \mathrm{yr}$ (water year 2001), with an average yield of 69.6 $\mathrm{lb} / \mathrm{mi}^{2} / \mathrm{yr}$. 
Phosphorus loads for Clear Brook were calculated using a regression model with four explanatory variables, including the natural $\log$ of streamflow, time, and the seasonal terms sine and cosine. Annual loads for total phosphorus ranged from $34.6 \mathrm{lb}$ (water year 2001) to $108 \mathrm{lb}$ (water year 1999), with an average annual load of $67.9 \mathrm{lb}$. Using the additional data from storm samples for total phosphorus greatly increased the calculated loads for total phosphorus; however, the load calculations still probably underpredict the actual load of phosphorus being transported from the Clear Brook watershed. Because the watershed is small and the response of the streamflow during periods of precipitation is fast, or flashy, several peaks in runoff can occur in one day, causing multiple periods of time when high concentrations of particulate phosphorus could be transported. This response would not be reflected in the daily timestep load model that was used in this study.

More than 49 percent of the annual load of total phosphorus during water year 1999 and 26 percent of the total phosphorus load during the study period was contributed from runoff during Tropical Storm Floyd in September 1999. In general, the remaining load was relatively evenly spread throughout each water year and was consistent with streamflow. Annual yields of total phosphorus from the Clear Brook watershed were less variable than yields from either the Phelps Brook or the Nepaug River watersheds. Annual yields from the Clear Brook watershed ranged from $54.9 \mathrm{lb} / \mathrm{mi}^{2} / \mathrm{yr}$ (water year 2001) to 171 $\mathrm{lb} / \mathrm{mi}^{2} / \mathrm{yr}$ (water year 1999) and averaged $108 \mathrm{lb} / \mathrm{mi}^{2} / \mathrm{yr}$. Average total phosphorus yields from the Clear Brook watershed were 40 percent less than the average total phosphorus yields from the Nepaug River watershed. Yield estimates for the Clear Brook watershed have a high bias because the topographic drainage area is smaller than the contributing area.

\section{Organic Carbon Loads and Yields}

Annual loads of total organic carbon in Nepaug River were estimated using a regression model that included natural log of streamflow, time, and the seasonal terms sine and cosine as explanatory variables. Annual loads of total organic carbon in the Nepaug River watershed ranged from 360,000 lb (water year 1999) to 444,000 lb (water year 2000) and averaged $401,000 \mathrm{lb}$. Total organic carbon yields ranged from 15,300 $\mathrm{lb} / \mathrm{mi}^{2} / \mathrm{yr}$ (water year 1999) to $18,900 \mathrm{lb} / \mathrm{mi}^{2} / \mathrm{yr}$ (water year 2000). The average annual yield of total organic carbon in the Nepaug River watershed was $17,000 \mathrm{lb} / \mathrm{mi}^{2} / \mathrm{yr}$.

Annual loads of total organic carbon in the Phelps Brook watershed were estimated using a regression model that included the natural log of streamflow and the seasonal components sine and cosine. Annual loads of total organic carbon in the Phelps Brook watershed ranged from 75,700 lb (water year 2001 ) to $83,200 \mathrm{lb}$ (water year 1999) and averaged 78,200 lb. Runoff from Tropical Storm Floyd in September 1999 contributed 46,700 lb, more than 50 percent of the annual load for that water year. The annual yields of total organic carbon for the study period ranged from $28,000 \mathrm{lb} / \mathrm{mi}^{2} / \mathrm{yr}$ (water year 2001) to
$30,800 \mathrm{lb} / \mathrm{mi}^{2} / \mathrm{yr}$ (water year 1999). The average annual yield of total organic carbon in the Phelps Brook watershed, 29,000 $\mathrm{lb} / \mathrm{mi}^{2} / \mathrm{yr}$, was the highest for all the watersheds in this study and was almost twice the total organic carbon yield from the Nepaug River watershed. The high annual yield is most likely caused by the wetlands and impoundments of Phelps Brook upstream from the sampling site on Smith and Valentine Roads. These impoundments tend to collect forest detrital material that is rich in organic carbon and convert this material into forms that are either suspended or soluble in water. The impoundments created by beaver dams also inundate terrestrial soils. The accumulated leaf litter and forest detrital material on these soils, as well as the organic carbon within the soils, reacts with the water and becomes available for export from the watershed.

Annual loads of total organic carbon in the Clear Brook watershed were estimated using a regression model that included the natural log of streamflow, the natural log of streamflow squared, time, and the seasonal components sine and cosine as explanatory variables. Annual loads of total organic carbon in the Clear Brook watershed ranged from 4,950 $\mathrm{lb}$ (water year 2000) to 5,460 lb (water year 2001) and averaged $5,170 \mathrm{lb}$. The annual yields of total organic carbon ranged from $7,860 \mathrm{lb} / \mathrm{mi}^{2} / \mathrm{yr}$ (water year 2000 ) to $8,670 \mathrm{lb} / \mathrm{mi}^{2} / \mathrm{yr}$ (water year 2001). The average yield of total organic carbon from Clear Brook was $8,210 \mathrm{lb} / \mathrm{mi}^{2}$, which is 25 percent of the average total organic carbon yield from the Nepaug River and 50 percent of the average total organic carbon yield from Phelps Brook. Yield estimates for the Clear Brook watershed have a high bias because the topographic drainage area is smaller than the contributing area. Potential sources of organic carbon in the Clear Brook watershed are from forest detrital material and wash-off from Clear Brook Road as well as some small wetland areas.

\section{Limitations of the Nutrient Load Models}

The 95-percent confidence intervals of the load estimates for the three stations combined ranged from 63 to 135 percent for total nitrogen and from 35 to 862 percent for total phosphorus. The largest confidence intervals are associated with total phosphorus from all three stations, because of loads contributed by Tropical Storm Floyd in September 1999.

Load estimates for total nitrogen and total phosphorus computed using the regression model were compared to loads computed by mass integration for four storms. An example of the results for one storm-May 1999-is shown in table 10. Comparing the mass-integrated storm loads from single storms to the daily load from each regression model indicates better agreement for total nitrogen than total phosphorus at the three stations; however, the confidence intervals for the daily estimates from the regression model limit any quantitative comparisons for short time periods representing single storms. 
Table 10. Example of a storm-load calculation of total phosphorus and total nitrogen by LOADEST and mass-integration methods for U.S. Geological Survey stations in the Nepaug Reservoir watershed, May 1999.

[ $\mathrm{ft}^{3} / \mathrm{s}$, cubic foot per second; lb/d as P, pound per day as phosphorus; $\mathrm{lb} / \mathrm{d}$ as N, pound per day as nitrogen; LOADEST is the regression model]

\begin{tabular}{|c|c|c|c|c|c|c|}
\hline Water-quality constituent & Method & $5 / 18 / 1999$ & 5/19/1999 & $5 / 20 / 1999$ & 5/21/1999 & $5 / 22 / 1999$ \\
\hline \multicolumn{7}{|c|}{ Station 01187800 Nepaug River near Nepaug, Connecticut } \\
\hline Daily streamflow $\left(\mathrm{ft}^{3} / \mathrm{s}\right)$ & & 12.0 & 47.0 & 253 & 77.0 & 37.0 \\
\hline \multirow{2}{*}{$\begin{array}{l}\text { Load of total phosphorus } \\
(\mathrm{lb} / \mathrm{d} \text { as } \mathrm{P})\end{array}$} & LOADEST & 1.00 & 7.3 & 151 & 16.9 & 5.17 \\
\hline & Mass integration & .80 & 9.10 & 95.6 & 28.9 & 3.54 \\
\hline \multirow{2}{*}{$\begin{array}{l}\text { Load of total nitrogen, } \\
(\mathrm{lb} / \mathrm{d} \text { as } \mathrm{N})\end{array}$} & LOADEST & 21.0 & 98.0 & 810 & 180 & 75.0 \\
\hline & Mass integration & 14.0 & 115 & 930 & 260 & 120 \\
\hline \multicolumn{7}{|c|}{ Station 01187850 Clear Brook near Collinsville, Connecticut } \\
\hline Daily streamflow $\left(\mathrm{ft}^{3} / \mathrm{s}\right)$ & & 2.00 & 2.90 & 2.50 & 2.10 & 2.10 \\
\hline \multirow{2}{*}{$\begin{array}{l}\text { Load of total phosphorus } \\
(\mathrm{lb} / \mathrm{d} \text { as } \mathrm{P})\end{array}$} & LOADEST & .17 & .54 & .34 & .20 & .20 \\
\hline & Mass integration & .10 & .64 & .15 & .11 & .10 \\
\hline \multirow{2}{*}{$\begin{array}{l}\text { Load of total nitrogen, } \\
(\mathrm{lb} / \mathrm{d} \text { as } \mathrm{N})\end{array}$} & LOADEST & 1.30 & 3.10 & 2.20 & 1.50 & 1.50 \\
\hline & Mass integration & .66 & 4.90 & 3.60 & 2.40 & 2.30 \\
\hline
\end{tabular}

Limited comparison demonstrates that total nitrogen load from the regression model was in closest agreement with the total nitrogen load from mass integration at Phelps Brook. The largest difference between the two methods was the underestimation by the regression method during the March 28, 2000 storm at Nepaug River. Total nitrogen load was overestimated by the regression method in the Nepaug River during two spring storm events. During a spring storm that spanned multiple days, the regression model used concentration values from the storm to estimate the time period without concentration data. This procedure overestimated the concentration on the receding limb, and subsequently, the total nitrogen load.

Both total nitrogen and total phosphorus loads were underestimated by the regression model for Clear and Phelps Brooks for all four storms analyzed. The rapid increase, sharp peak, and subsequent decrease in the streamflow hydrographs reflect the small size of these watersheds. The rapid streamflow changes and coinciding concentration changes are not well represented by the daily time step of the regression model, which is based on the daily mean streamflow value and daily average nutrient concentration.

\section{Comparison of Yields in the Nepaug Reservoir Watershed to Other Watersheds in Connecticut}

Annual total nitrogen yields for the three watersheds ranged from $741 \mathrm{lb} / \mathrm{mi}^{2} / \mathrm{yr}$ to $2,050 \mathrm{lb} / \mathrm{mi}^{2} / \mathrm{yr}$ (table 9 ) and correspond to the range of values for other watersheds in Connect- icut with mostly forested land and either no or few point-source wastewater discharges. Annual total nitrogen yields for watersheds of the Farmington River at Unionville (378 $\left.\mathrm{mi}^{2}\right)$, Salmon River near East Hampton $\left(100 \mathrm{mi}^{2}\right)$, and Saugatuck River near Redding $\left(21 \mathrm{mi}^{2}\right.$ ) ranged from 480 to $2,900 \mathrm{lb} / \mathrm{mi}^{2} / \mathrm{yr}$ for the period 1988-98 (Mullaney and others, 2002), and 651 to 3,520 $\mathrm{lb} / \mathrm{mi}^{2} / \mathrm{yr}$ for the period $1986-95$ (Trench, 2000). Yields of total nitrogen for these watersheds differ considerably between years because of climatic and hydrologic factors.

Annual yields of total phosphorus for the Farmington, Salmon, and Saugatuck Rivers ranged from 31 to $339 \mathrm{lb} / \mathrm{mi}^{2} / \mathrm{yr}$ for the period 1986-95 (Trench, 2000). These values are similar to the range of 51 to $228 \mathrm{lb} / \mathrm{mi}^{2} / \mathrm{yr}$ for the total phosphorus yields calculated for the three watersheds in this study. The range of total phosphorus yields also is comparable to the range of 47.7 to $267 \mathrm{lb} / \mathrm{mi}^{2} / \mathrm{yr}$ reported by Morrison (2002) for Sasco Brook, a forested watershed with higher percentages of agricultural and mixed residential land use than the Nepaug Reservoir area.

Data from two National Atmospheric Deposition Program (NADP) stations-CT15 in Abington, Connecticut, and MA08 at the Quabbin Reservoir in central Massachusetts-show that total nitrogen yields from the three study watersheds are relatively low compared to atmospheric contributions. Atmospheric-deposition yields were calculated from annual yields of nitrate and ammonia from the NADP stations during the 2000 and 2001 water years (unpublished data accessed 8/25/2004 on the World Wide Web at URL http://nadp.sws.uiic.edu/). Yields 
of total nitrogen for the study watersheds ranged from 741 to $2,050 \mathrm{lb} / \mathrm{mi}^{2} / \mathrm{yr}$, and the atmospheric-deposition yields of nitrogen ranged from 6,810 to $9,560 \mathrm{lb} / \mathrm{mi}^{2} / \mathrm{yr}$ at CT15 and from 8,910 to $11,600 \mathrm{lb} / \mathrm{mi}^{2} / \mathrm{yr}$ at MA08. The difference of more than 400 percent between the yields from atmospheric deposition and maximum yields from the three watersheds indicates substantial attenuation of nitrogen in the watersheds.

\section{Summary and Conclusions}

The U.S. Geological Survey and the Metropolitan District Commission conducted a cooperative, three-phase study to evaluate potential effects of sand and gravel mining on streamflow and the quality of water entering Nepaug Reservoir, a reservoir in northwestern Connecticut, that supplies drinking water to Hartford and surrounding communities. As part of the study, streamflow and water quality in the three tributary streams that enter the Nepaug Reservoir were investigated. Streamflow-gaging stations were operated and water samples were collected from Nepaug River, Phelps Brook, and Clear Brook. Water samples were collected monthly for analyses of nutrients, organic carbon, major ions, and fecal indicator bacteria. Samples for analyses of nutrients and organic carbon also were collected during selected storms during the study period (19992001), and continuous water-quality monitors were used for varying time periods to examine changes in selected waterquality constituents at short time scales.

The pattern of streamflow was quite different among the three watersheds during the study period. Streamflow in the Nepaug River and Phelps Brook varied throughout the year, whereas streamflow in Clear Brook remained fairly constant. Streamflow in Clear Brook is highly affected by the large percentage of ground-water discharge in the watershed. As a result, the hydrologic response of Clear Brook is relatively stable streamflows that are buffered against periods of extreme high and low streamflows. Because of substantial ground-water contributions, the annual runoff per square mile from Clear Brook was consistently higher than runoff from either Phelps Brook or Nepaug River; this difference points to a topographic drainage area that is smaller than the contributing area.

Measurements of physical and chemically related properties indicated that water during base flow was of low turbidity, low ionic strength, neutral $\mathrm{pH}$, and well oxygenated. Most changes to water quality took place during storms. Turbidity was highly variable at and among all three sites during runoff. Major ion concentrations were highly variable in Nepaug River and Phelps Brook during base flow, and were less variable during storms. In contrast, major ion concentrations and specific conductance values in Clear Brook varied little during base flow. Major ion concentrations and specific conductance tended to decrease during runoff in all three watersheds. The lower major ion concentration and specific conductance were a result of low ionic strength of the precipitation. Although chloride concentrations were lower than those in other watersheds with similar land use in Connecticut, chloride concentrations were elevated in Nepaug River and Phelps Brook as compared to Clear Brook; this result is consistent with the lack of public roads or residential development in the Clear Brook watershed.

Data from the routine monthly water samples show that water quality in the Nepaug Reservoir watershed is generally good and meets the standards established for drinking-water supply for nitrate, but does not always meet contact-recreation standards for bacteria. Although the three tributaries differ in size, base streamflow, and land uses, concentrations of most dissolved constituents were low and indicate a largely natural, forested watershed with few indicators of human activity. The highest concentrations of total nitrogen and total phosphorus during base flow were in Phelps Brook, followed by Nepaug River and Clear Brook. During the study, the maximum values for total nitrogen and total phosphorus were in samples collected during storms and were measured at Clear Brook. Median concentrations of nitrite plus nitrate were highest in Nepaug River and lowest in Clear Brook. Total concentrations of nitrogen during base flow in Clear Brook were commonly below the reporting limit; this result is consistent with nutrients moving primarily with storm runoff.

Concentrations of total organic carbon in Nepaug River and Phelps Brook were highly variable during base flow. The effect of increased streamflow on total organic carbon concentration was different among the three stations. As streamflow increased at Nepaug River and Clear Brook, concentrations of total organic carbon increased. As streamflow increased at Phelps Brook, concentrations of total organic carbon decreased, probably because the high concentration that developed by slow movement of the water through the wetlands was diluted by rapid runoff through the wetlands following storms.

During the 3-year study period, the geometric means of fecal coliform and enterococci bacteria counts were generally below state contact-recreation standards at the three stations. Fecal coliform and enterococci bacteria counts were largest at Nepaug River during a runoff event in June 2001. The contactrecreation standard for enterococci was exceeded 16 times-9 times in the Nepaug River. Statistical comparison of the data indicated that fecal coliform counts at Nepaug River and Phelps Brook were larger than those at Clear Brook. Enterococci counts were larger at Nepaug River than at either Phelps Brook or Clear Brook. No correlation was found between streamflow and bacteria counts for either fecal coliform or enterococci. Seasonal differences were found between summer and winter sampling periods. A possible explanation for the higher counts at Nepaug River may be attributed to differences in the watershed-larger populations of warm-blooded animals and humans, larger size of the contributing watershed, more residential land use, more septic systems, more agriculture, or some combination of all these factors.

Nutrient loads were estimated by regression analysis for the three stations to describe the quantity and timing of nutrient delivery to the Nepaug Reservoir. Spring runoff from the streams delivered about 33 percent of the annual total nitrogen load. Single storm runoff events can deliver a large percentage 
of the annual total nitrogen load in any of the three watersheds. For example, Tropical Storm Floyd in September 1999 delivered more than 20 percent of the annual total nitrogen load at each of the three stations.

Total phosphorus loads in spring were 25 to 33 percent of the annual load at the three stations. As with total nitrogen, single storm runoff events can deliver large percentages of the annual total phosphorus load. Runoff from Tropical Storm Floyd in September 1999 delivered 57, 47, and 49 percent of the annual total phosphorus load to the Nepaug River, Phelps Brook, and Clear Brook, respectively. Although total nitrogen and total phosphorus loads were both strongly affected by streamflow, total phosphorus loads were larger during extreme events (high flows) because of the close association of this nutrient with sediment transport.

The timing and percentage of annual total organic carbon loads delivered to the Nepaug Reservoir were comparable to those of total nitrogen loads. Spring runoff delivered 20 to 33 percent of the annual total organic carbon load. Runoff from Tropical Storm Floyd in September 1999 delivered more than 50 percent of the yearly total organic carbon load at Phelps Brook. In contrast, the same storm accounted for 33 percent of the total organic carbon load at Clear Brook. Except for the spring period and the tropical storm, the loads at the Clear Brook station were evenly distributed throughout the year.

Defining the role of hydrology during base flow and storm flow at each site is an important step toward understanding the mechanisms that deliver water and water-quality constituents (nutrients and total organic carbon) to the reservoir. Data from the three stations indicate that high streamflow events, especially during spring, are the most important factor in the delivery of nutrient loads and sediment to the reservoir. Spring streamflow during the study period for the three sites ranged from 30 to 56 percent of the yearly streamflow entering the reservoir. As demonstrated during Tropical Storm Floyd in September 1999, however, high streamflow can take place at other times of the year, and a single storm can deliver a large percentage of the yearly load of suspended material.

On the basis of data collected in this study, it appears that most nutrients in the watershed are sediment-bound and are transported during storms. Managing nutrient inputs to the Nepaug Reservoir will reduce nuisance algae blooms and help lower the cost of water treatment, reduce potential taste and odor problems in the treated water supply, and reduce problems associated with disinfection by-products from organic matter produced in the reservoir. In addition, understanding the potential positive and negative effects that beaver ponds can have on water quality would be helpful for developing watershed management plans. Beaver ponds can have the positive effect of reducing peak streamflows and limiting sediment and sedimentbound nutrients, but the ponds also can increase the export of total organic carbon from the watershed. Managing watershed lands to reduce the number and size of beaver ponds that contribute large amounts of organic carbon to the reservoir could also help reduce water-treatment problems associated with disinfection by-products.
Removal of the unsaturated zone (for example, by sand and gravel mining) in the Nepaug Reservoir watershed could change the quality and quantity of the water that is delivered to the reservoir. Mining sand and gravel from Clear Brook, along with removal of vegetation and top soil and the steepening of slopes, could cause more frequent and greater surface-water runoff during storms, greater erosion during storms, quicker precipitation return to the river, and more nutrient export from the watershed. All of these factors could result in higher concentrations of suspended sediment with associated nutrients. Scheduling mining and forestry activities in the watershed to not coincide with periods that are sensitive to spring runoff or runoff from large storms may limit the negative effects of nutrient enrichment and sedimentation in the Nepaug Reservoir.

\section{Acknowledgments}

The authors would like to thank Leland Sanders and Carol Youell of the Metropolitan District Commission for their assistance during this study. In addition, the authors would like to thank the following current and former U.S. Geological Survey employees: Jason Lewis, Heather Sirotnak, Karen Beaulieu, and Rylan Farr for collection of water-quality samples; Mary Ellen Ley, Douglas Moyer, and Daniel Hippe for technical reviews; and Barbara Korzendorfer for assistance with report preparation and layout.

\section{References Cited}

Aiken, G.R., Costaris, E., 1995, Soil and hydrology-Their effect on NOM: Journal of American Water Works Association, v. 87, no. 1, p. 36-45.

Britton, L.J., and Greeson, P.E., eds., 1989, Methods for collection and analysis of aquatic biological and microbiological samples: U.S. Geological Survey Techniques of WaterResources Investigations, book 5, chap. A4, 363 p.

Brown, A.V., Lyttle, M.M., and Brown, K.B., 1998, Impacts of gravel mining on gravel bed streams: American Fisheries Society, v. 127, p. 979-994.

Chatterjee, S., and McLeash, D.L., 1986, Fitting linear regression models to censored data by least squares and maximum likelihood methods: Communications in Statistics-Theory and Methods, v. 15, no. 11, p. 3227-3243.

Civco, D.L., and Hurd, J.D., 1990, Connecticut land use and land cover inventory: Storrs, Conn., University of Connecticut Department of Natural Resources, Geographic Information System coverage.

Clark, G.M., Mueller, D.K., and Mast, M.A., 2000, Nutrient concentrations and yields in undeveloped stream basins of the United States: Journal of American Water Resources Association, v. 36, no. 4, p. 849-867. 
Cohn, T.A., Delong, L.L., Gilroy, E.J., Hirsch, R.M., and Wells, D.K., 1989, Estimating constituent loads: Water Resources Research, v. 25, no. 5, p. 937-942.

Connecticut Department of Environmental Protection, 1996, State of Connecticut water quality standards: Bureau of Water Management, Planning and Standards Division, p. 32. Connecticut Department of Environmental Protection, 2002, State of Connecticut 2002 water-quality report to Congress: Bureau of Water Management, Planning and Standards Division, variously paginated.

Crawford, C.G., 1991, Estimation of suspended-sediment rating curves and mean suspended-sediment loads: Journal of Hydrology, v. 129, p. 331-348.

Crawford, C.G., 1996, Estimating mean constituent loads in rivers by the rating-curve and flow-duration, rating-curve methods: Bloomington, Indiana, Indiana University, Ph.D. dissertation, $245 \mathrm{p}$.

Dempster, A.P., Laird, N.M., and Rubin, D.B., 1977, Maximum likelihood from incomplete data via the EM algorithm: Journal of the Royal Statistical Society, Series B, v. 39, no. 1, p. $1-22$.

Dingman, S.L., 1994, Physical hydrology: Englewood Cliffs, N.J., Prentice Hall, 575 p.

Edwards, T.K., and Glysson, G.D., 1988, Field methods for measurement of fluvial sediment: U.S. Geological Survey Open-File Report 86-531, 118 p.

Efron, B., 1982, The Jackknife, the Bootstrap and Other Resampling Plans: Philadelphia, Pa., Society for Industrial and Applied Mathematics, $92 \mathrm{p}$.

Femmer, S.R., 2002, Instream gravel mining and related issues in southern Missouri: U.S. Geological Survey Fact Sheet 012-02, 4 p.

Gilroy, E.J., Hirsch, R.M., and Cohn, T.A., 1990, Mean square error of regression-based constituent transport estimates: Water Resources Research, v. 26, p. 2069-2077.

Helsel, D.R., and Hirsch, R.M., 2002, Statistical methods in water resources: U.S. Geological Survey Techniques of Water-Resources Investigations, book 4, chap. A3, 510 p.

Hemond, H.F., and Benoit, Janina, 1988, Cumulative impacts of water-quality functions: Environmental Management, v. 12 , p. 639-653.

Insightful, Inc. 2000, S-PLUS 6.1 modern statistics and advanced graphics computer software.

Likes, Jiri, 1980, Variance of the MVUE for lognormal variance: Technometrics, v. 22, no. 2, p. 253-258.

Mondazzi, R.A., and Starn, J.J., 2003, Hydrogeology and quality of ground water in unconsolidated glacial deposits in the Nepaug Reservoir watershed, New Hartford and Burlington, Connecticut: U.S. Geological Survey Open-File Report 03$350,28 \mathrm{p}$.

Morrison, Jonathan, 2002, Water quality and streamflow in Sasco Brook watershed, southwestern Connecticut: U.S. Geological Survey Water-Resources Investigations Report 02-4002, $30 \mathrm{p}$.
Morrison, Jonathan, Provencher, P.L., Martin, J.W., and Norris, J.R., 2002, Water resources data, Connecticut, water year 2001: U.S. Geological Survey Water-Data Report CT-01-1, $353 \mathrm{p}$.

Mullaney, J.R., and Grady, S.J., 1997, Hydrogeology and water quality of a surficial aquifer underlying an urban area, Manchester, Connecticut: U.S. Geological Survey WaterResources Investigations Report 97-4195, 40 p.

Mullaney, J.R., Schwarz, G.E., and Trench, E.C.T., 2002, Estimation of nitrogen yields and loads from basins draining to Long Island Sound, 1988-98: U.S. Geological Survey WaterResources Investigations Report 02-4044, 84 p.

Mullaney, J.R., and Zimmerman, M.J., 1997, Nitrogen and pesticide concentrations in an agricultural basin in north-central Connecticut: U.S. Geological Survey Water-Resources Investigations Report 97-4076, 13 p.

Nalley, G.M., and Haefner, R.J., 1999, Simulation of the effects of nearby quarrying operations on ground-water flow at the South Well Field, Franklin County, Ohio: U.S. Geological Survey Water-Resources Investigations Report 99-4136, $23 \mathrm{p}$.

National Oceanic and Atmospheric Administration, 1998-2001, Climatological data, annual and monthly summaries, New England, 1998-2001: Asheville, North Carolina, National Oceanic and Atmospheric Administration, v. 110-113, variously paginated.

Novotny, V., and Olem, H., 1994, Water quality-Prevention, identification, and management of diffuse pollution: New York, Van Nostrand Reinhold, 1054 p.

Pomes, M.L., Green, W.R., Thurman, E.M., Orem, W.H., and Lerch, H.E., 1999, DBP formation potential of aquatic humic substances: Journal of American Water Works Association, v. 91, no. 3, p. 103-115.

Rantz, S.E., and others, 1982, Measurement and computation of streamflow-volume 1. Measurement of stage and discharge: U.S. Geological Survey Water-Supply Paper 2175, 284 p.

Ranzau, C.E., Jr., Davies, B.S. 3rd, Frick, T.W., and Organek, J.A., 2001, Water resources data, Connecticut, water year 2000: U.S. Geological Survey Water-Data Report CT-00-1, 333 p.

Ranzau, C.E., Jr., Frick, T.W., Norris, J.R., and Martin, J.W., 2000, Water resources data, Connecticut, water year 1999: U.S. Geological Survey Water-Data Report CT-99-1, 351 p.

Reckhow, D.A., Singer, P.C., and Malcolm, R.L., 1990, Chlorination of humic materials-By-product formation and chemical interpretations: Environmental Science and Technology, v. 24, no. 11, p. 1655-1664.

Runkel, R.L., Crawford, C.G., Cohn, T.A., 2004, Load estimator (LOADEST) - A FORTRAN program for estimating constituent loads in streams and rivers: U.S. Geological Survey Techniques and Methods, book 4, chap. A5, 69 p. 
Stone, J.R., Starn, J.J., and Morrison, Jonathan, 2001, Hydrogeology of sand and gravel deposits near the Nepaug Reservoir, New Hartford and Burlington, Connecticut: U.S. Geological Survey Water-Resources Investigations Report 01-4059, $38 \mathrm{p}$.

Trench, E.C.T., 2000, Nutrient sources and loads in the Connecticut, Housatonic, and Thames River Basins: U.S. Geological Survey Water-Resources Investigations Report 994236, 66 p.

Wagner, R., 2000, Guidelines and standard procedures for continuous water-quality monitors-Site-selection, field operation, calibration, record computation, and reporting: U.S. Geological Survey Water-Resources Investigations Report 00-4252, $53 \mathrm{p}$.

Waldron, M.C., and Bent, G.C., 2001, Factors affecting reservoir and stream-water quality in the Cambridge, Massachusetts, drinking-water source area and implications for sourcewater protection: U.S. Geological Survey Water-Resources Investigations Report 00-4262, 89 p.

Waters, T.F., 1995, Sediment in streams-Sources, biological effects, and control: American Fisheries Society Monograph 7.

Wetzel, R., 1983, Limnology (2d ed.): Philadelphia, Pa., Saunders College Publishing, 767 p.

Wilde, F.D., and Radtke, D.B., 1998, National field manual for the collection of water quality data- Field measurements: U.S. Geological Survey Techniques of Water-Resources Investigations, book 9, chap. A6, variously paginated.
Wilde, F.D., Radtke, D.B., Gibs, Jacob, and Iwatsubo, R.T., 1998a, National field manual for the collection of water quality data-Preparation for water sampling: U.S. Geological Survey Techniques of Water-Resources Investigations, book 9, chap. A1, 47 p.

Wilde, F.D., Radtke, D.B., Gibs, Jacob, and Iwatsubo, R.T., 1998b, National field manual for the collection of water quality data-Selection of equipment for water sampling: U.S. Geological Survey Techniques of Water-Resources Investigations, book 9, chap. A2, 94 p.

Wilde, F.D., Radtke, D.B., Gibs, Jacob, and Iwatsubo, R.T., 1998 c, National field manual for the collection of water quality data-Cleaning of equipment for water sampling: U.S. Geological Survey Techniques of Water-Resources Investigations, book 9, chap. A3, 75 p.

Wilde, F.D., Radtke, D.B., Gibs, Jacob, and Iwatsubo, R.T., 1999a, National field manual for the collection of water quality data-Collection of water samples: U.S. Geological Survey Techniques of Water-Resources Investigations, book 9, chap. A4, 156 p.

Wilde, F.D., Radtke, D.B., Gibs, Jacob, and Iwatsubo, R.T., 1999b, National field manual for the collection of water quality data-Processing of water samples: U.S. Geological Survey Techniques of Water-Resources Investigations, book 9, chap. A5, 149 p.

Wolynetz, M.S., 1979, Algorithm 139-Maximum likelihood estimation in a linear model with confined and censored data: Applied Statistics, v. 28, p. 195-206. 
